\title{
Haematophagous arthropod saliva and host defense system: a tale of tear and blood
}

\author{
BRUNO B. ANDRADE ${ }^{1,2}$, CLARISSA R. TEIXEIRA ${ }^{1,2}$, ALDINA BARRAL BLA $^{1,2,3}$ \\ and MANOEL BARRAL-NETTO ${ }^{1,2,3}$ \\ ${ }^{1}$ Centro de Pesquisas Gonçalo Moniz (FIOCRUZ-BA) \\ Rua Waldemar Falcão, 121, 40295-001 Salvador, BA, Brasil \\ ${ }^{2}$ Faculdade de Medicina, Universidade Federal da Bahia/UFBA \\ Av. Reitor Miguel Calmon s/n, Vale do Canela, 40110-100 Salvador, BA, Brasil \\ ${ }^{3}$ Instituto de Investigação em Imunologia (iii) - Instituto do Milênio \\ Manuscript received on June 20, 2005; accepted for publication on June 23, 2005; \\ contributed by ALDINA BARRAL* AND MANOEL BARRAL-NETTO*
}

\begin{abstract}
The saliva from blood-feeding arthropod vectors is enriched with molecules that display diverse functions that mediate a successful blood meal. They function not only as weapons against host's haemostatic, inflammatory and immune responses but also as important tools to pathogen establishment. Parasites, virus and bacteria taking advantage of vectors' armament have adapted to facilitate their entry in the host. Today, many salivary molecules have been identified and characterized as new targets to the development of future vaccines. Here we focus on current information on vector's saliva and the molecules responsible to modify host's hemostasis and immune response, also regarding their role in disease transmission.
\end{abstract}

Key words: saliva, bites, hemostasis, host, vector, infection.

\section{INTRODUCTION}

Blood-feeding arthropods can require vertebrate host blood for nutrition, egg development, and survival. The medical and public health importance of these ectoparasites is evident because of the alarming emergence of new vector-borne infectious agents and the resurgence of previously known ones. The morbidity and mortality of infectious diseases transmitted by blood-feeding arthropods were more expressive than all other causes in the last centuries (Gubler 1998).

\footnotetext{
*Member, Academia Brasileira de Ciências Correspondence to: Manoel Barral-Netto, MD

E-mail: mbarral@cpqgm.fiocruz.br
}

Haematophagous vectors of disease are not regarded simply as tools for the delivery of their pathogens. Advances in biomedical research focused on the role of blood-feeding arthropods saliva in the transmission of some infectious diseases have shown the presence of a co-evolutionary relationship between these vectors and the pathogen they transmit. Rather, vector's saliva seems to be a potent pharmacologically active fluid that directly affects the haemostatic, inflammatory and immune responses of vertebrate host (Ribeiro 1995a).

Before blood meal, haematophagous arthropods must locate blood by introducing their mouthparts into the vertebrate host skin tearing tissues and lacerating capillaries, which creates hem- 
orrhagic pools upon which it feeds. Such insects as triatomine bugs feed directly from inside venules and arterioles, after been guided by an initial hemorrhagic pool (Lavoipierre 1965, Ribeiro 1987b). During this process insect's saliva is injected into the host's skin at the site of the bite. This saliva contains a great variety of haemostatic, inflammatory and immunomodulatory molecules such as proteins, prostaglandins, nucleotides, and nucleosides that locally modify the physiology of the host, making an adequate microenvironment for parasitism. Pathogens transmitted by these vectors interact with both saliva components and host mediators taking advantage of the altered host physiology to become established (Belkaid et al. 2000, Jones et al. 1992, Titus and Ribeiro 1988).

Understanding mammalian response to insect's saliva is of utmost importance in several ways. Besides being related to allergy (Reunala et al. 1994, Shan et al. 1995) insect's saliva is known to facilitate parasite survival (Belkaid et al. 1998, Kamhawi 2000, Samuelson et al. 1991). Arthropod saliva is also related with specific antibody production by humans and other vertebrates against its components (Brummer-Korvenkontio et al. 1994, Feingold and Benjamini 1961, Wikel 1996). Conversely, host immunity to vector saliva may decrease infectivity of the transmitted pathogens (Belkaid et al. 1998, Bell et al. 1979). These responses can be used as epidemiological markers of vectors exposure (Barral et al. 2000, Schwartz et al. 1990, 1991) and also support the possibility to prevent and treat allergic responses and to develop anti-arthropod vaccines.

Accordingly, the purpose of this review is to expose the salivary molecules that have been identified and characterized in various blood-feeding arthropods and its activities related to host's defense, including hemostasis and immune response. Indeed, we also focus on the role of saliva in parasite transmission and recent data suggesting that salivary peptides are an alternative target for the control of pathogen transmission through the development of effective vaccines.

\section{ARTHROPOD SALIVA AND HOST HEMOSTASIS: THE BLOOD QUEST}

Attempting to probe and feed, blood-sucking arthropods must circumvent the host haemostatic system. Host hemostasis is highly sophisticated and efficient process that includes several redundant pathways geared towards overcoming blood loss; among which are blood-coagulation cascade, vasoconstriction, and platelet aggregation (Ribeiro 1987b, 1995a). These components act together leading to the arrest of blood flow at the site of vessel lesion. To overcome these obstacles, blood-feeding arthropods have evolved within its salivary secretions an array of potent pharmacological components, such as anticoagulants, anti-platelet and vasodilators (Champagne 1994, Ribeiro 1995a, Stark and James 1996b). As a rule, blood-suckers' saliva contains at least one anticlotting, one antiplatelet, and one vasodilatory substance (Ribeiro and Francischetti 2003). In many cases, more than one molecule exists in each category and in some, a molecule alone is responsible for more than one anti-haemostatic effect. For example, compounds such as adenosine and nitric oxide that are once antiplatelet and vasodilatory are found in saliva. Salivary molecules responsible for these effects on host hemostasis have been characterized and some proteins were isolated, indicating the possibility to neutralize these mechanisms.

\section{Platelet Aggregation}

The first host's mechanism to avoid blood loss during tissue injury seems to be platelet aggregation. Platelets can be activated by diverse stimulus including collagen exposure, thrombin interaction, thromboxane $\mathrm{A}_{2}$ and ADP. After activated, platelets aggregate, promote clotting, and release vasoconstrictor mediators to form the platelet plug. Blood feeders can inhibit this aggregation through different ways. Anophelin, a peptide from Anopheles albimanus saliva (Fig. 1f) that behaves as an alphathrombin inhibitor, also contributes for the anticlotting phenomena observed in experimental es- 
says (Valenzuela et al. 1999). The salivary gland homogenate of the tick Rhodnius prolixus (Fig. 1d) presents a $19 \mathrm{kDa}$ protein named Rhodnius prolixus aggregation inhibitor 1 (RPAI-1) that inhibits collagen-induced platelet aggregation by binding to ADP (Francischetti et al. 2000), the same effect observed by a molecule with similar sequence and structure (pallidipin) isolated from saliva of Triatoma pallidipennis (Fig. 1d) (Noeske-Jungblut et al. 1994). The deerfly Chrysops spp. saliva (Fig. 1a, $\mathrm{b}$ and d) can prevent platelet aggregation induced by ADP, thrombin and collagen, and also inhibits fibrinogen, binding to the glycoprotein IIb/IIIa receptor on platelets (Grevelink et al. 1993). ADP has a key function in hemostasis through induction of platelet aggregation and derives from activated platelets and injured cells (Vargaftig et al. 1981). Thus, it is not surprisingly that the most common molecule involved in inhibition of platelet aggregation encountered on the majority of blood feeding arthropods seems to be the salivary apyrase enzyme, that hydrolyses ATP and ADP to AMP and orthophosphate, preventing the effect of ADP on hemostasis. However, at least two different families of this enzyme exist and both known families require $\mathrm{Ca}^{2+}$ and/or $\mathrm{Mg}^{2+}$ for their action. Aedes aegypti (Champagne et al. 1995b), Anopheles (Arca et al. 1999) and Culex mosquitoes (Fig. 1e) (Nascimento et al. 2000) present in their saliva apyrases from the same family of 5'-nucleotidases. A novel apyrase enzyme sequence was found recently in the salivary glands of the haematophagous bed bug Cimex lectularius (Valenzuela et al. 1998) and homologous sequences were found in the sand flies Lutzomia longipalpis (Charlab et al. 1999) and Phlebotomus papatasi (Valenzuela et al. 2001), indicating that this family of enzymes is widespread among arthropod species (Fig. 1e). This novel apyrase functions exclusively with $\mathrm{Ca}^{2+}$. It is important to show that, in the sand flies salivary components analyzed, a salivary 5'- nucleotidase was also found in L. longipalpis but not in P. papatasi (Fig. 1e) (Charlab et al. 1999). Finally, the salivary apyrase from Triatoma infestans (Fig. 1e) also belongs to the 5'-nucleotidase family (Faudry et al. 2004) and are peculiarly dependent of $\mathrm{Mn}^{2+}$ and $\mathrm{Co}^{2+}$ (Ribeiro et al. 1998).

Platelet function can also be antagonized by substances that increase platelet cyclic adenosine monophosphate (cAMP) or cyclic guanosine monophosphate (cGMP). Previous work had demonstrated that prostaglandin $\mathrm{E}_{2}\left(\mathrm{PGE}_{2}\right)$ and prostacyclin obtained from tick's saliva can increase platelet cyclic nucleotides (Higgs et al. 1976). Nitric Oxide (NO) released within saliva of the bugs Rhodnius prolixus and Cimex lectularius (Fig. 1g) activates the cytosolic guanylate cyclase enzyme, causing an anti-clotting effect (Ribeiro et al. 1993, Vogt 1974).

\section{BLOOD-COAgUlation CASCADE}

The blood-coagulation cascade is launched by various mechanisms set by injury to blood vessels. It ends in the production of active thrombin, which cleaves fibrinogen to fibrin, the clot protein. The fibrin polymerizes and forms the blood clot, providing rigidity to the platelet plug. Salivary anticoagulants from blood-feeding arthropods seems to target specific proteases or complexes of the bloodcoagulation cascade, blocking or delaying the clot formation process until the blood feeder finishes the meal (Ribeiro 1987b). Different insects have evolved diverse molecules responsible for these actions, which effectiveness also varies by species. Many of these salivary molecules are in different stages of molecular characterization. Most salivary anticoagulants target components in the final common pathway of the coagulation cascade, including factors V, Xa and II (thrombin). For example, anophelin is a unique peptide isolated from the saliva of Anopheles albimanus (Fig. 2f) that functions as a specific and tight-binding thrombin inhibitor (Noeske-Jungblut et al. 1995, Valenzuela et al. 1999). Another mosquito, Aedes aegypti, (Fig. 2d) present within its saliva a $48 \mathrm{kDa}$ peptide factor Xa inhibitor that was purified, cloned, expressed and shown to be a member of the serpin 


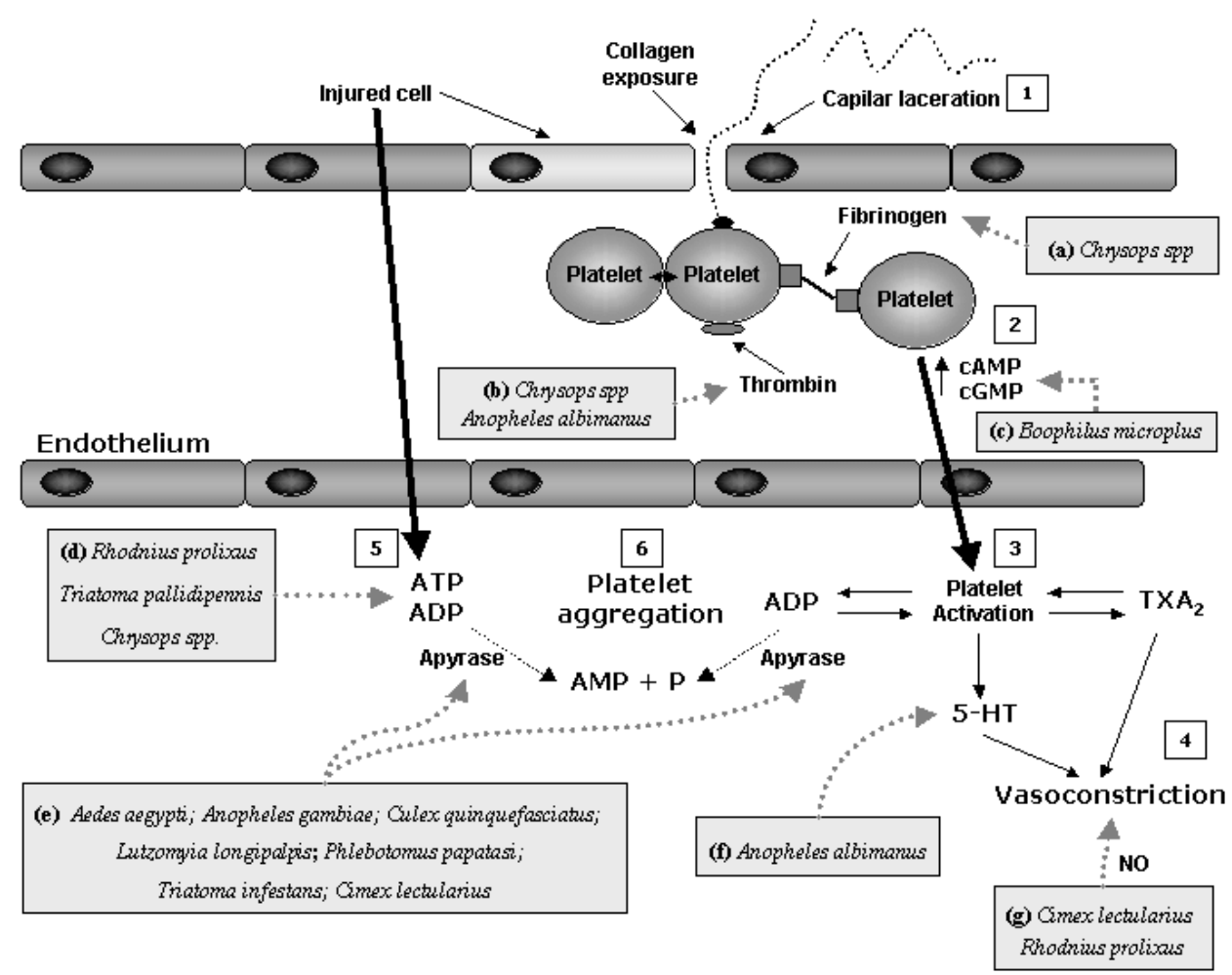

Fig. 1 - Vector's saliva acting on platelet activation and aggregation: (1) Blood feeding vectors induce vessel laceration and tissue injury resulting in collagen exposure when probing for a blood meal. (2) Thus, platelets aggregate, promoting clotting, and release of vasoconstrictor mediators promoting hemostasis. Blood feeders can inhibit platelet aggregation by preventing fibrinogen, thrombin (Anopheles albimanus and Chrysops spp.) or cAMP/cGMP stimulation (Boophilus microplus). (3) Platelet activation and degranulation also occur after thromboxane $\mathrm{A}_{2}$ that results in vasoconstrictor response and (4) the NO present within bug's saliva can prevent haemostatic effect (Cimex lectularius and Rhodnius prolixus).(5) They can also bind to ADP (Rhodnius prolixus, Triatoma pallidipennis and Chrysops spp.) or (6) Prevent the action of ADP through salivary apyrase to prevent platelet aggregation (Aedes aegypti, Anopheles gambiae, Culex quinquefasciatus, Lutzomyia longipalpis, Phlebotomus papatasi, Triatoma infestans and Cimex lectularius).

family of serine protease inhibitors (Stark and James 1998). Salivary gland extract of Culicoides variipennis (the primary North America vector of bluetongue viruses) (Fig. 2d) contains a factor $\mathrm{Xa}$ inhibitor similarly to all the subfamily of culicine mosquitoes (Perez de Leon et al. 1997). It has been proposed that despite variation in the degree of inhibition, all anophelines have thrombin directed anticoagulants and culicine mosquitoes have factor $\mathrm{Xa}$ directed anticoagulants. Differences in the site of action of the anticoagulants must likely reflect the long period of independent adaptation of the two subfamilies to the challenges presented by vertebrate hemostasis (Stark and James 1996a).

A potent and specific low molecular mass $(3,530 \mathrm{Da})$ anticoagulant peptide purified from salivary gland of Glossina morsiatans morsiatans (Fig. 2f) is a thrombin inhibitor (Cappello et al. 1996, 1998). This peptide is a stoichiometric inhibitor of thrombin and also a potent inhibitor of thrombin-induced platelet aggregation.

Subtractive cloning combined with biochem- 
ical approaches was used to discover activities in the salivary glands of the haematophagous sand fly Lutzomyia longipalpis (Charlab et al. 1999). Sequences of nine full-length complementary DNA (cDNA) clones were obtained and five were possibly associated with blood meal acquisition, each having cDNA similarity to: (a) the bed bug Cimex lectularius apyrase, (b) a 5'-nucleotidase/phosphodiesterase, (c) a hyaluronidase, (d) a protein containing a carbohydrate-recognition domain (CRD), and (e) a unique RGD-containing peptide. This work was the first to identify a hyaluronidase activity in a haematophagous insect salivary gland. The CRDprotein and the RGD containing peptide seem to be involved in anticlotting activities.

Triatomine bugs also evolved potent anticoagulants, as factors V and VIII inhibitors from Triatoma infestans (Fig. 2c and e) (Pereira et al. 1996) and triabin, a salivary 142-reside protein of Triatoma pallidipennis (Fig. 2f) that selectively interacts with thrombin, exclusively via its fibrinogen recognition exosite (Fuentes-Prior et al. 1997). Prolixin S (nitrophorin 2), from salivary gland extracts of Rhodnius prolixus (Fig. 2c) inhibits coagulation factor VIII-mediator activation of factor X and accounts for all the anti-clotting activity observed in its saliva (Ribeiro et al. 1995). Saliva of the hard tick and Lyme disease vector, Ixodes scapularis (Fig. 2d), was genetically sequenced in a cDNA library. In this process, a clone with sequence homology to tissue factor pathway inhibitor was identified and this cDNA codes for a mature protein, herein called ixolaris, with 140 amino acids. Observations of ixolaris function evidenced the blockage of factor Xa generation by endothelial cells expressing tissue factor. This work also demonstrated that ixolaris uses factor X and Factor VIIa as scaffolds for the inhibition of factor VIIa/Tissue factor complex (Fig. 2a) (Francischetti et al. 2002).

\section{VASOCONSTRICTION}

Arachdonic acid is released by activated platelets when blood vessels are lacerated by arthropods' mouthparts and is converted by other platelet enzymes into thromboxane $\mathrm{A}_{2}$, a powerful plateletaggregating, platelet-dagranulating, and vasoconstricting substance (Ribeiro 1987b). Activated platelets also release serotonin, which together with thromboxane $A_{2}$ is responsible for the early vasoconstrictor response in local inflammation caused by tissue injury (Weigelt et al. 1979). Saliva from blood feeder insects presents vasodilatory substances or molecules that antagonize vasoconstrictors produced on the site of tissue injury caused by inoculation of mouthparts during probing. These molecules act directly or indirectly on smoothmuscle cells activating intracellular enzymatic pathways that lead to cAMP or cGMP formation. Sialokinin, a tachykinin decapeptide from Aedes aegypti, is a vasodilator through activating nitric oxide production by endothelial cells via cGMP induction (Champagne and Ribeiro 1994).

Maxadilan, a $6.5 \mathrm{kDa}$ peptide encoded by a gene cloned from Lutzomyia longipalpis salivary glands, is the most potent salivary vasodilator known until now and also has immunomodulatory properties (Lerner et al. 1991, Lerner and Shoemaker 1992). The vasodilatory effect of maxadilan is endothelium independent and correlates with an increase of cAMP in smooth muscle cells (Grevelink et al. 1995), acting as a specific agonist of the pituitary adenylate cyclase activating polypeptide (PACAP) type I receptor on vascular and neural tissues and also on macrophage surface (Moro and Lerner 1997, Moro et al. 1996). The presence of adenosine and its precursor 5'-AMP has been demonstrated in salivary glands of Phlebotomus papatasi (Ribeiro et al. 1999) and Phlebotomus argentipes (Ribeiro and Modi 2001), with vasodilatory, antiplatelet-aggregation and immunomodulatory properties (Collis 1989, Dionisotti et al. 1992, Lewis et al. 1994). Note that Phlebotomus insects do not have maxadilan and Lutzomyia do not have adenosine in their saliva. These differences in pharmacological strategies among sand flies from the same family, but from genera that diverged not early 


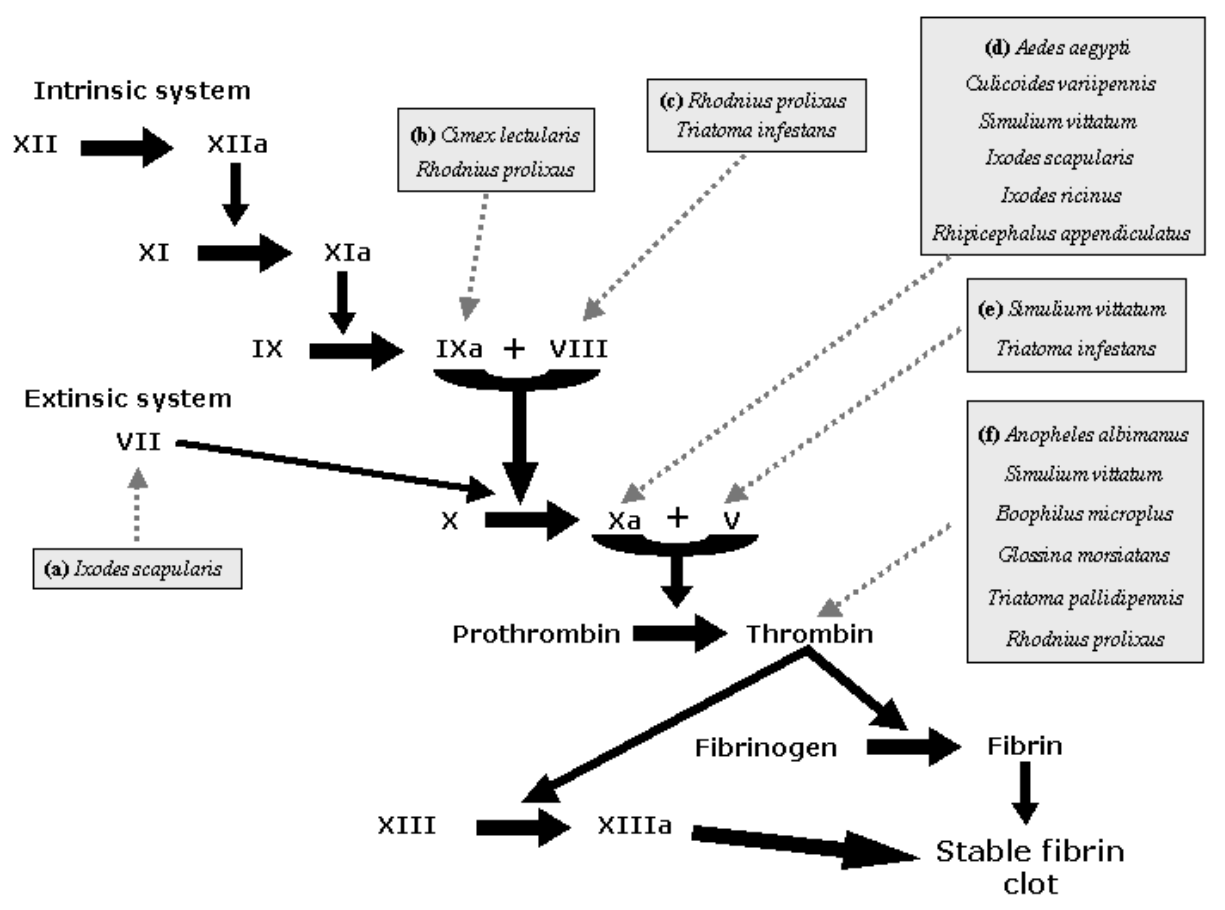

Fig. 2 - Blood-coagulation cascade (intrinsic and extrinsic system) activated in response to tissue injury is also blocked by salivary molecules. The blood-coagulation cascade is activated after blood vessels injury resulting in the production of active thrombin, which cleaves fibrinogen to fibrin that polymerizes forming a stable clot blocking blood loss. Salivary anticoagulants from blood feeding arthropods inhibit specific targets of the coagulation cascade. They target components such as factor IXa (Cimex lectularius and Rhodnius prolixus); VIII (Rhodnius prolixus and Triatoma infestans); Xa (Aedes aegypti, Culicoides variipennis, Simulium vittatum, Ixodes scapularis, Ixodes ricinus and Rhipicephalus appendiculatus); V (Simulium vittatum and Triatoma infestans), VII (Ixodes scapularis) and thrombin (Anopheles albimanus, Simulium vittatum, Boophilus microplus, Glossina morsiatans, Triatoma pallidipennis and Rhodnius prolixus) resulting in inhibition or delayed blood-thrombin (Anopheles albimanus, Simulium vittatum, Boophilus microplus, Glossina morsiatans, Triatoma pallidipennis and Rhodnius prolixus) and coagulation response.

than the last separation of the continental plates, stresses the diversity of compounds found in the salivary glands of blood-feeder arthropods (Ribeiro et al. 1999). Finally, the black fly Simulium vittatum salivary gland has a $15 \mathrm{kDa}$ vasodilator that acts on ATP-dependent K-channels and has no structural similarity to other known proteins (Cupp et al. 1994, 1998).

Another example of salivary vasodilator is prostaglandin $\mathrm{E}_{2}\left(\mathrm{PGE}_{2}\right)$ and prostaglandin $\mathrm{F}_{2}$ $\left(\mathrm{PGF}_{2}\right)$ demonstrated from salivary gland homogenate of different tick species (Dickinson et al.
1976, Ribeiro et al. 1985). $\mathrm{PGE}_{2}$ and prostacyclin dilate host's blood vessels, thus antagonizing the vasoconstrictor component of hemostasis thromboxane $\mathrm{A}_{2}$. The triatomine bug Rhodnius prolixus releases NO within its saliva, as does the cimicid bug Cimex lectularius (Ribeiro et al. 1993, Vogt 1974). To carry this volatile substance to the host tissue, these bugs developed a different heme protein (nitrophorins) that reversibly binds and stabilizes NO making viable to release this gas in the host skin. Rhodnius nitrophorin is a member of the lipocalin family (Champagne et al. 1995a) and 
Cimex nitrophorin is a member of the inositol phosphatase family (Valenzuela et al. 1995). Because Cimex lectularius and Rhodnius prolixus belong to different hemipteran families (Cimucidae and Reduvidae, respectively) and evolved independently to blood-feeding, Cimex lectularius and Rhodnius prolixus nitrophorins may represent a case of convergent evolution (Valenzuela et al. 1995). In the case of Rhodnius prolixus, four NO-carrying proteins were isolated and named N1-N4 nitrophorins (Champagne et al. 1995a). Interestingly, the main nitrophorin from this triatomine has a very high affinity to histamine, a common autacoid found by blood-feeding insects on the skin of allergic hosts. Histamine binds to nitrophorin and further displaces NO at the site of injury. Thus, this nitrophorin also works as an anti-histaminic substance (Ribeiro 1995a).

Anopheline mosquitoes do not produce vasodilatory substances, but rather secrete a peroxidase enzyme that has significant NADPH oxidase activity. The NADPH oxidation produces $\mathrm{H}_{2} \mathrm{O}_{2}$, which is used by the enzyme to destroy serotonin and catecholamines, thus inactivating host's physiologic vasoconstrictor substances that may interfere with insect feeding (Ribeiro 1995a, Ribeiro and Valenzuela 1999).

Indeed, haematophagy evolved independently in several orders of insects and ticks. For this reason, a variety of salivary anti-haemostatic compounds are found in these diverse groups of arthropods. The combined effects of apyrases, prostaglandins, antithrombotics, anti-clotting and many classes of vasodilators effectively counteract host hemostasis and increase the chance of blood-suckers survivor.

\section{SALIVA AND HOST IMMUNE SYSTEM: BREAKING DOWN THE ENEMY}

IMMUNOMODULATORY PROPERTIES OF BLOODFEEDER ARTHROPODS SALIVA COMPONENTS

After repeated exposure to salivary antigens, host immune system may elaborate cellular (delayed- type hypersensitivity, DTH) and/or humoral reactions that will alter the local site of probing that may result on rejection of the ectoparasite (Wikel 1982). This host's resistance is related to a Th1 immune response, with significant production of interferon (IFN)- $\gamma$, interleukin (IL)-2 and IL-12. To face this problem, blood-feeding arthropods have evolved salivary immunomodulatory factors which prevent host from becoming sensitized to the vasomodulatory substances of saliva that facilitate blood meal (Gillespie et al. 2000) or even retard deleterious host responses. Such factors induce a Th2 deviation of host's immune response, which favors insect survivor. Many types of immunomodulatory molecules have been isolated from different bloodfeeding arthropod species. Most of these mediators act directly or indirectly on immune effectors cells, like macrophages, T cells, B cells, Natural Killer (NK) cells and granulocytes.

Certain activities observed are common to all vectors, for example the inflammation inhibitors (anti-complement properties), the cytokines/chemokines modulators and anti-coagulants (Sandemam 1996, Wikel 1996). For both rapidly feeding insects and slowly feeding ticks, the reduction of host immunity to their salivary components enhances the likelihood that a host will be a suitable source of future blood meals (Schoeler and Wikel 2001). Hard ticks remain attached to the host for days and this long interaction generates a vigorous host's response to tick bite and its salivary components, resulting in rejection of these parasites (Ribeiro 1995a). Rapidly feeding insects, such as sand flies, also induce an intense DTH response at the site of the bite. Interestingly, the larger blood flow encountered at the DTH site favors the sand flies to probe and feed faster (Belkaid et al. 2000). Arthropod modulation of host immunity could provide the appropriate environment for pathogen transmission and establishment, which could be combined with, or followed by, immune evasion mediated by the infectious agent (Ribeiro 1987c). Increasing body of evidence is supporting this view. 


\section{INNATE IMMUNE RESPONSE}

Innate immune system consists of all the immune defenses that lack immunologic memory. Innate responses frequently involve complement, acutephase proteins besides granulocytes, mast cells, dendritic cells, macrophages, and NK cells. Complement components, prostaglandins, leukotrienes and other inflammatory inductors all contribute to the recruitment of inflammatory cells to the site of ectoparasite exposure. Thus, these cells and inflammatory mediators represent the first line of immune defense against blood-feeding arthropods likely affecting its feeding process.

The early events of complement activation are based on an enzymatic amplifying cascade comparable to that seen in blood clotting. The complement fragments $\mathrm{C} 3 \mathrm{a}, \mathrm{C} 4 \mathrm{a}$ and $\mathrm{C} 5 \mathrm{a}$ activate mast cells, which release histamine, cytokines and other proinflammatory substances (Delves and Roitt 2000). C5a also acts as a powerful neutrophil chemoattractant. The complement components C5b, C6 C7, C8, and C9 form the membrane-attack complex (Delves and Roitt 2000), which perforates cell membranes and may lead to the death of the lining cells of insect's mouthparts. The alternative pathway of complement seems to be involved in expression of blood-feeding arthropod resistance (Wikel 1979). Thus, the anaphylatoxins C3a and C5a cause further release of vasoactive mediators, which increase vascular permeability and potentiate the accumulation of antibodies and immune cells at the site of the bite. Despite these obstacles, bloodsuckers are capable of having a successful blood meal likely through host immunomodulation by salivary components. Saliva of the tick Ixodes dammini (Fig. 3a) antagonizes anaphylatoxin and bradykinin likely by the presence of a carboxypeptidase (Ribeiro and Spielman 1986) and can also inhibit C3a release and C3b deposition (Ribeiro 1987a). Saliva of Lutzomyia longipalpis is capable of inhibiting both the classical and alternative Complement pathways (Fig. 3a), whereas that of Lutzomyia migonei acted only on the former (Cavalcante et al. 2003). The triatomine bugs Panstrongylus megistus, Triatoma brasiliensis and Rhodnius prolixus (Fig. 3a) were also able to inhibit the classical pathway whereas the mosquito Aedes aegyti and flea Ctenocephalides felis were not (Cavalcante et al. 2003).

The molecules collectively referred to as acutephase proteins enhance host resistance to infection and promote the repair of damaged tissue (Delves and Roitt 2000). Plasma levels of these proteins change rapidly in response to infection, inflammation and tissue injury. In addition to some complement components, the acute-phase proteins include $\mathrm{C}$ - and $\mathrm{S}$ - reactive proteins, serum amyloid A protein, proteinase inhibitors and anticoagulant peptides. These substances or their function may be altered by arthropod salivary components for the success of blood meal (Cappello et al. 1996, Horn et al. 2000, Noeske-Jungblut et al. 1995, Paesen et al. 1999).

Host's mast cells, loaded with histamine and serotonin have high-affinity receptors to $\operatorname{IgE}$. These cells are activated and degranulate in the presence of divalent ectoparasite antigens cross linked with two IgE, releasing their vasoactive amines that leads to local edema and erythema. After activation, mast cells produce and release several arachidonic acid metabolites and a diversity of cytokines, including IL-4 and tumor necrosis factor (TNF)- $\alpha$, which stimulate the immune response to progress toward a Th2 or antibody mediated response. Mast cells are also responsible for the production of nerve-growing molecules, such as bradykinin, serotonin and histamine (Boyce 2004). Some blood-suckers salivary components can interfere in these processes. For example, extracts of Aedes aegypti's salivary glands (Fig. 3c) inhibit the release of TNF- $\alpha$ from rat mast cells, but do not inhibit antigen-induced histamine secretion (Bissonnette et al. 1993). Salivary adenosine deaminase activity has been demonstrated in two culicine mosquitoes (Ribeiro et al. 2001) Aedes aegypti, Culex quinquefasciatus, and in the sand fly Lutzomyia longipalpis (Fig. 3c) (Char- 
lab et al. 2000), but not in the anopheline Anopheles gambiae (Ribeiro et al. 2001). The adenosine deaminase activity in Aedes aegypti may help blood feeding by removing adenosine, a molecule associated with both pain perception inhibition and induction of mast cell degranulation in vertebrates, and by producing inosine, a molecule that potently inhibits the production of inflammatory cytokines (Ribeiro et al. 2001). Bradykinin and histamine are important mediators of itch (Alexander 1986) and pain (Clark 1979) which could stimulate host grooming and removal of the blood feeding arthropod. It is perhaps not surprising that the some insects' salivary glands, like Ixodes scapularis (Ribeiro and Mather 1998) and Rhodnius prolixus (Ribeiro and Walker 1994) contain kininases that inhibit bradykinin. Indeed, hard ticks also produce histamine-binding proteins that minimize local inflammation host's response (Chinery and Ayitey-Smith 1977, Paesen et al. 1999). Finally, data suggest that saliva of Triatoma infestans can inhibit sodium channels activity in nerves by an unspecified molecule, with potential antinociceptive effects (Dan et al. 1999).

Arthropods' saliva can induce immune suppression of innate immune cells. Ixodes dammini (Fig. 3b) salivary gland homogenate inhibits rat neutrophils function (Ribeiro et al. 1990). Salivary gland extracts (SGE) from Dermacentor reticulatus (Fig. 3f) adult ticks induce a decrease in human natural killer (NK) activity acting on the first step of NK cell activity, namely effector/target cell conjugate formation (Kubes et al. 2002). NK cell cytotoxicity as well as NO production by macrophages are inhibited by Ixodes ricinus SGE (Kopecky and Kuthejlova 1998) and by Phlebotomus papatasi (Fig. 3f) saliva (Ribeiro et al. 1999, Waitumbi and Warburg 1998). The saliva of this phlebotomine also contains a potent inhibitor of protein phosphatase 1 and protein phosphatase $2 \mathrm{~A}$ of murine macrophages, suggesting that the Phlebotomus papatasi salivary phosphatase inhibitor may interfere with the ability of activated macrophages to transmit signals to the nucleus, thereby preventing up regulation of the induced nitric oxide synthase gene inhibiting the production of NO (Katz et al. 2000, Waitumbi and Warburg 1998). Adenosine and its precursor 5'AMP, also isolated from Phlebotomus papatasi (Fig. 3d) salivary glands (Katz et al. 2000, Ribeiro et al. 1999) have been reported to enhance IL-6, IL-10, IL-4 and $\mathrm{PGE}_{2}$ production, and together with inosine (product of adenosine deaminase) were shown to decrease the production of IL-12, IFN$\gamma$, TNF- $\alpha$ and NO (Hasko et al. 2000, Hasko et al. 1998, Hasko et al. 1996, Le Moine et al. 1996, Link et al. 2000). In the presence of salivary glands extracts of Lutzomyia longipalpis (Fig. 3d), macrophages were unable to present antigen, were refractory to activation by IFN- $\gamma$ and were unable to produce $\mathrm{H}_{2} \mathrm{O}_{2}$ or NO (Hall and Titus 1995, Theodos and Titus 1993, Titus and Ribeiro 1990). This inhibition seems to be selective, as it did not alter the ability of IFN- $\gamma$ to up regulate MHC class II expression on their surfaces. On human monocytes, salivary gland homogenate (SGH) of Lu. longipalpis induces an increase in IL-6, IL-8, and IL-12p40 production, but a decrease in tumor necrosis factor and IL-10 production. SGH also affects the expression of co-stimulatory molecules (CD80 and CD86) on the surface of human monocytes and macrophages (Fig. 3d). A reduction in CD80, CD86, HLA-DR and CD1 a molecules during Dendritic cell (DC) differentiation from human monocytes and maturation induced by CD40L after SGH stimulation is also observed (Fig. 3e) (Costa et al. 2004). DCs play a major role in host immune responses through processing and presenting arthropod salivary antigens to T-lymphocytes in draining lymph nodes. Rhipicephalus sanguineus (Fig. 3e) tick saliva inhibits the differentiation of DC and decreases the population of differentiated immature DC. Furthermore, maturation of DC stimulated by lipopolysaccharide (LPS) in the presence of saliva resulted in a lower expression of costimulatory (CD40, CD80 and CD86) molecules and also reduced production of interleukin-12 (Cavassani et al. 2005). Rather, DC cultured with tick saliva revealed them to be poor 
stimulators of cytokine production by antigenspecific T cells.

Further studies showed that maxadilan, through activation of PACAP type 1 receptor, inhibited the expression of TNF- $\alpha$ by macrophages and increased levels of the cytokines IL-6 and IL-10 as well as prostaglandin $\mathrm{E}_{2}$ (Bozza et al. 1998, Lanzaro et al. 1999, Soares et al. 1998). Maxadilan, as well as whole salivary gland lysate suppressed type 1 responses and enhanced type 2 responses by human PBMC and purified monocyte cultures in vitro (Rogers and Titus 2003). Maxadilan decreased IFN- $\gamma$, IL-12 and TNF- $\alpha$ production, while increasing IL-6 secretion by human PBMC few hours after stimulation with Leishmania major or LPS. Indeed, it was suggested that this Lutzomyia longipalpis vasodilator could interfere on the IFN- $\gamma$ release through the suppression of IL-12 production by T-lymphocytes (Fig. 3g), possibly as a result of changes induced in macrophages and NK cells. Interestingly, it has been found that the primary amino acid sequence of maxadilan peptide is polymorphic (Lanzaro et al. 1999) and sibling species within the Lutzomyia longipalpis complex present significant differences in their amounts of maxadilan mRNA (Yin et al. 2000). Despite these differences, the vasodilatory activity appears not to be altered (Lanzaro et al. 1999). The maxadilan primary sequence polymorphism may represent an evolutionary vantage to the sand fly, preventing the host from becoming sensitized to this important peptide and, consequently, the loss of blood meal. It has also been proposed that differences in salivary components of different geographical populations of sand flies may be responsible for the differences observed in clinical manifestation of visceral leishmaniasis in America (Warburg et al. 1994). So, different strategies of host immunomodulatory appear to have evolved for Old-World and New-World sand flies.

The observations above show us that bloodfeeding arthropods evolved strategic mechanisms to evade or suppress the innate immune response and that saliva of ectoparasites may have a key role in this process.

\section{ACQUIRED IMMUNE RESPONSE}

Immunoglobulin and $\mathrm{T}$ cell mediated immune responses are induced during the first exposure to ectoparasites feeding. The ability of an animal to respond to a given molecule depends upon the genetically defined capacity to process and present them to immunocompetent $\mathrm{T}$ lymphocytes in context of major histocompatibility complex (MHC) antigens. Variations are expected in the abilities of randomly bred animals to develop and express resistance to arthropod feeding or any infectious agent. Blood-feeding arthropod salivary immunogens are largely processed for presentation to immunocompetent lymphocytes by Langehans cells, which are located in a suprabasal position within the epidermis (Schoeler and Wikel 2001). Also, these antigen presenting cells (APC) can transport immunogens to the draining lymph node, promoting antibody and cell mediated responses, which eventually clear blood-sucker salivary antigens from the skin. Together with Langerhans cells and dendritic cells, macrophages and NK cells seems to link the two instances of immune responses, innate (unspecific) and acquired (highly specific). An influx of host lymphocytes and macrophages (generating the DTH response), basophils, and eosinophils is observed at the site of the bite and circulating and homocytotropic antibodies (primary $\operatorname{IgM}$ and IgE, switching at late-phase to IgG isotype) are produced (Belkaid et al. 2000, Ferreira et al. 2003, Schoeler and Wikel 2001). Indeed, memory B and $\mathrm{T}$ lymphocytes are generated as a result of this initial exposure to blood-feeder salivary immunogens. Haematofagous arthropod feeding upon a resistant host induces a very different pattern of responsiveness. The presence of reactive antibodies and effector $\mathrm{T}$ lymphocytes assures a rapid response to infestation. If memory B and $\mathrm{T}$ lymphocytes need to be stimulated, the response will become maximal within a few days of re-infestation and can impair the ability of the arthropod to obtain a blood meal. For 


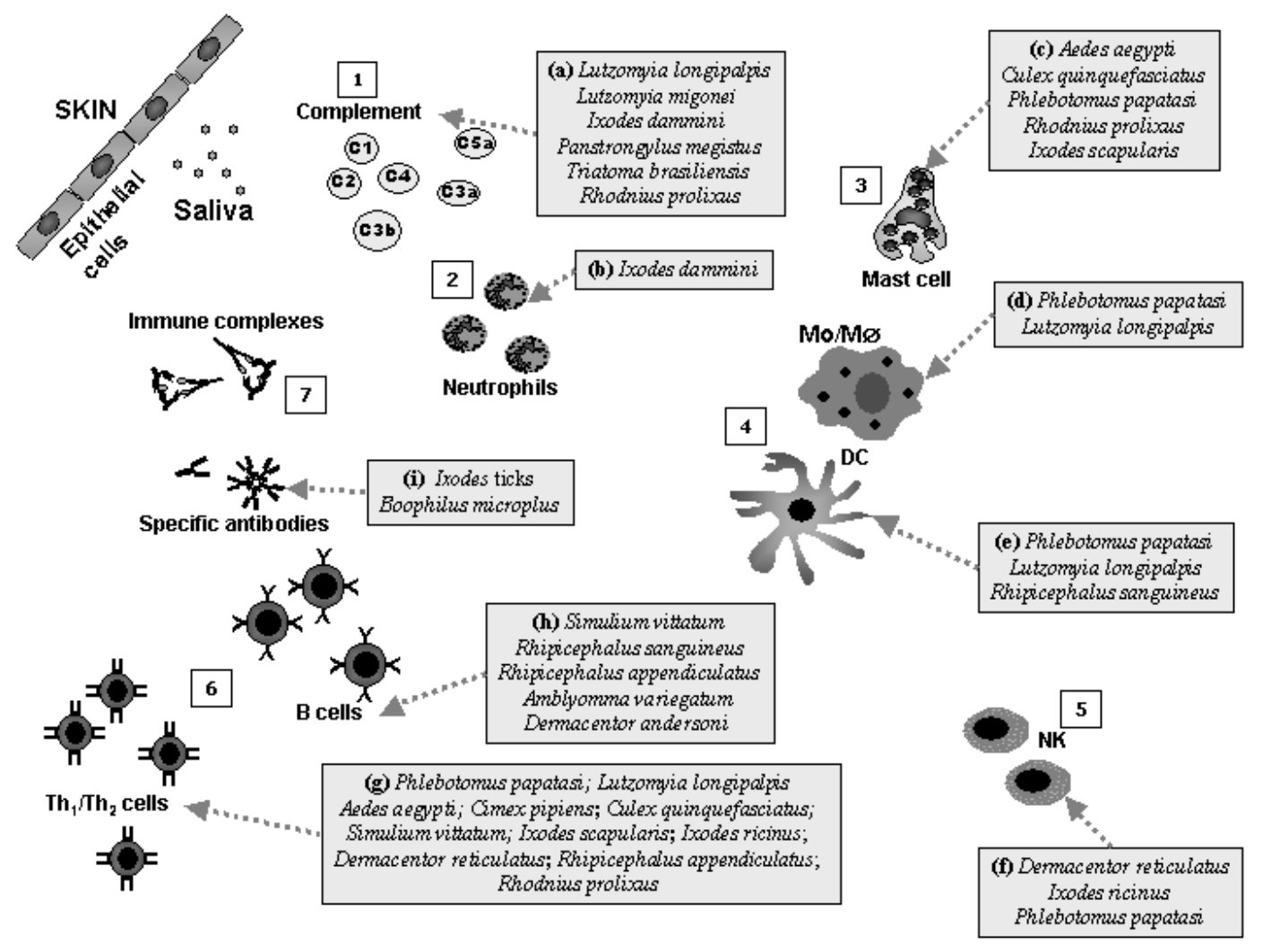

Fig. 3 - Host immune response is modified by arthropod's saliva. Salivary molecules can act on different effector cells and mediators of the immune system: (1) The complement system: inhibition of complement release of vasoactive mediators and cell activation in both classical and alternative pathways (Lutzomyia longipalpis, Ixodes dammini, Panstrongylus megistus, Triatoma brasiliensis and Rhodnius prolixus); (2) Neutrophils: inhibition of neutrophil function (Ixodes dammini); (3) Mast cells: reduction of mast cell degranulation and release of inflammatory mediators (Aedes aegypti, Culex quinquefasciatus, Phlebotomus papatasi, Rhodnius prolixus and Ixodes scapularis); (4) Antigen Presenting Cells: macrophages: inhibition of macrophage activation (Phlebotomus papatasi and Lutzomyia longipalpis) and dendritic cells: reduction of dendritic cell differentiation, maturation and cytokine production (Phlebotomus papatasi, Lutzomyia longipalpis and Rhipicephalus sanguineus); (5) NK cells: reduction of NK cell cytotoxicity (Dermacentor reticulatus, Ixodes ricinus and Phlebotomus papatasi); (6) Lymphocytes: B cells: inhibition of cell proliferation and modulation of immunoglobulin production (Simulium vittatum, Rhipicephalus sanguineus, Rhipicephalus appendiculatus, Amblyomma variegatum and Dermacentor andersoni) and T cells: modulation of cytokine production, reduced proliferative response and impaired leukocyte traffic (Phlebotomus papatasi, Lutzomyia longipalpis, Aedes aegypti, Cimex pipiens, Culex quinquefasciatus, Simulium vittatum, Ixodes scapularis, Ixodes ricinus, Dermacentor reticulatus, Rhipicephalus appendiculatus and Rhodnius prolixus) and (7) Antibodies and Immune Complexes: modification of immunoglobulin responses profile (Boophilus microplus and Ixodes ticks). 
a hard tick, the development of a DTH response by an unnatural host pre-exposed to its salivary components in the site of the bite may lead to the rejection of the insect (Ribeiro 1995b), while other insects, like sand flies, take advantage to this process, feeding twice as fast at the site of inflammation, that presents a larger blood flow than normal skin (Belkaid et al. 2000). In the case of ticks, the rejection is rarely seen in natural association and it seems that bugs co-evolved with the host to overcome the immune response (Ribeiro 1995b).

Thus, blood-feeding ectoparasites developed strategies to suppress host acquired immune responses. Ability to alter host defenses might be a factor in determining the range of hosts a particular species can parasite. In this way, a thorough understanding of the molecules involved in induction of host immunossuppression can be extremely important in the identification of vaccine immunogens.

\section{Cellular Immune Response And} CYTOKINE NETWORK

Cytokines act as cellular messengers, forming an integrated network that is highly involved in regulation of innate immunity and orchestrating, together with lymphocytes, all the components of acquired immune responses. In this section we explore these aspects of host's immunoregulation by most important blood-feeding arthropod species that have been studied.

Ticks are significant vectors of infectious diseases to both humans and animals. Ticks feeding on the host seem to have a systemic immunosuppressive effect on the host's immune system, including lymphocytes. Lymphocytes from tick-infested experimental animals had greatly reduced responses to mitogens in vitro (Wikel 1982, Wikel et al. 1978, Wikel and Osburn 1982). This effect has subsequently been demonstrated in vitro using the saliva or salivary gland extracts of several different species of hard ticks (Ferreira and Silva 1998, Fuchsberger et al. 1995, Ramachandra and Wikel 1992, 1995, Ribeiro et al. 1985, Urioste et al. 1994). Tick sali- vary $\mathrm{PGE}_{2}$ was primarily thought to be responsible for this lymphocytic suppressive effect (Inokuma et al. 1994, Ramachandra and Wikel 1992, Ribeiro et al. 1985). The down-regulation of T- or B-lymphocytes and macrophages by $\mathrm{PGE}_{2}$ was previously demonstrated on in vitro studies (Bahl et al. 1991, Phipps et al. 1991, Spatafora et al. 1991) and it is very likely the prostaglandins would have some effects on the immune system of the host. Ixodes scapularis saliva (Fig. 2g) can inhibit IL-2 through a soluble IL-2 binding proteic factor presented in its saliva. (Gillespie et al. 2001). IL-2 activates T cells and IL-2 receptors have been described on many cell types including B cells, macrophages and NK cells (Siegel et al. 1987, Smith 1992, Theze et al. 1996) highlighting the importance of this simple cellular inhibitory mechanism. Saliva of another tick, Ixodes ricinus (Fig. 3g), is able to reduce the concanavalin A (Con A)-or PHA-induced lymphoproliferation (Schorderet and Brossard 1993, Urioste et al. 1994). This reduction in responsiveness occurred in parallel with a decrease in the IL-2 secretion by the splenocytes exposed to the saliva. Another study showed a reduction of splenic cell proliferative response to B-cell mitogens in BALB/c mice given four sequential infestation with Ixodes ricinus (Fig. 3h), but the response to Con A or PHA were slightly enhanced (Dusbabek et al. 1995). Few differences were detected in regard to the ConA- or LPS-stimulated in vitro responses of splenocytes from $\mathrm{C} 3 \mathrm{H} / \mathrm{HeJ}$ mice that were tick-naive or had been infested one to four times with Ixodes scapularis (Schoeler et al. 2000). However, antigenspecific proliferative responses to soluble, salivary gland proteins of Ixodes scapularis (Fig. 3g) did develop in the mouse lymphocytes during the course of the infestations (Schoeler et al. 1999). Concurrent with the development of these responses there was a decrease in expression of the Th1 cytokines, IL-2 and IFN- $\gamma$, and an up-regulation of the Th2 cytokines, IL-4 and IL-10 in susceptible animals (Schoeler et al. 1999, Zeidner et al. 1997). These effects were not seen in resistant BALB/c mice, sug- 
gesting a basis of genetic predisposition in $\mathrm{C} 3 \mathrm{H} / \mathrm{HeJ}$ mice strain to Ixodes scapularis infestation.

Mice stimulated with saliva from Rhipicephalus sanguineus (Fig. 3g) induced transforming growth factor (TGF)- $\beta$ production while IL-12 was reduced. Susceptible mice exposed to tick infestation modulated the immune response drastically reducing proliferation of lymph node cells after Con A stimulation and a production of Th2 cytokine represented by IL-4, IL-10 and TGF- $\beta$ (Ferreira and Silva 1999). A similar response was observed in dogs (susceptible host) infested with this tick, they had a reduced proliferative reaction and a significant immediate but no DTH response to a cutaneous test induced by tick extract, whereas guinea pigs (resistant host) developed a strong DTH reaction (Ferreira et al. 2003).

Extracts prepared from the salivary glands of Rhipicephalus appendiculatus ticks (Fig. 3g) reduced the expression of IFN- $\alpha$, TNF- $\alpha$, IL- $1 \alpha$, IL- $1 \beta$, IL-5, IL-6, IL-7 and IL- 8 by LPS-stimulated human peripheral blood leukocytes (Fuchsberger et al. 1995). Thus, the saliva of these ticks may stimulate the deviation of host's immune system to a Th2 pattern, favoring the blood-sucker's survival. Work with saliva from Dermacentor andersoni (Fig. 3g) (Bergman et al. 1995, 1998) has shown that a protein of approximately $36 \mathrm{kDa}$ is responsible for suppression of $\mathrm{T}$ cell proliferation by an unknown mechanism (Bergman et al. 1995). Tick salivary components can also alter the leukocyte traffic and the interactions between activated endothelial cells and adhesion molecules on the leukocyte surface. Splenic lymphocytes of mice infested with Dermacentor andersoni (Fig. 3g), as well as normal lymphocytes exposed to its saliva, had reduced expression of some of these adhesion molecules: leukocyte function-associated antigen-1 (LFA-1) and very late activation-4 (VLA-4) integrins (Macaluso and Wikel 2001). Therefore, Dermacentor andersoni salivary compounds can facilitate blood meal through retarding cellular migration and modifying the population of host's immune cells at the site of tick attachment, also altering the activation pattern of these cells, creating an adequate microenvironment for parasitism.

Rhodnius prolixus is an important vector of Trypanosoma cruzi, the causative agent of Chagas disease. Spontaneous and mitogen-induced mouse lymphocyte proliferation were suppressed by Rhodnius prolixus (Fig. 3g) blood feeding (Kalvachova et al. 1999).

Besides tick bugs, black flies are capable of modulating their hosts' immune defense. Mice inoculated with a salivary gland extract (SGE) of the black fly Simulium vittatum (Fig. $3 \mathrm{~g}$ and $\mathrm{h}$ ) have reduced expression of major histocompatibility complex (MHC) class-II antigens on their splenocytes and even showed an in vitro (but not in vivo) inhibition of B- and T-lymphocyte mitogenesis (Cross et al. 1993a). It is possible that such changes interfere subtly with antigen-presentation as mice repeatedly exposed to Smulium vittatum SGE exhibited differential responses to ovalbumin (OVA) immunizations compared to control animals. Splenocytes from SGE-treated mice produced lower levels of IL-5 and IL-10 but not of IFN- $\gamma$, IL-2 and IL-4, upon OVA challenge than cells from mice treated with saline (Cross et al. 1994b).

Sand flies are the most extensively studied blood feeding insects in regard to modulation of host immune defenses (Charlab et al. 1999, Gillespie et al. 2000, Wikel 1999a). The adenosine deaminase contained in salivary extracts from Lutzomyia longipalpis (Fig. 3g) can suppress $\mathrm{T}$ cell apoptosis besides inhibition of IL-12, IFN- $\gamma$, TNF$\alpha$ and NO production (Charlab et al. 2000). The most important immunomodulatory substance isolated was the peptide maxadilan. Besides its effects on blood vessel smooth muscles and macrophages, maxadilan can also interfere in T-lymphocytes physiology, leading to an inhibition of the DTH reactions in mouse foot-pads (Qureshi et al. 1996). An effect on T-lymphocyte proliferation was determined by adding maxadilan to mouse splenocytes stimulated with Con A or anti-T-lymphocyte receptor 
(Qureshi et al. 1996). The observed modulation of macrophage and T-lymphocyte functions could have arisen to prevent development of immune responses to the salivary gland proteins in the host, which are introduced into the site of the bite and are essential for successful blood feeding. Despite the absence of maxadilan peptide within Phlebotomus papatasi salivary glands (Fig. $3 \mathrm{~g}$ ), the saliva of this phlebotomine can also interfere on T-lymphocyte function through the inhibition of Th1 protective cytokines (IFN- $\gamma$ and IL-12) production while enhancing the exacerbative cytokine IL-4 (Belkaid et al. 1998, Mbow et al. 1998).

Aedes aegypti SGE (Fig. 3g) added to cultures of Con A- or OVA-stimulated naive murine splenocytes caused significant suppression of IL-2 and IFN- $\gamma$ production, but not of IL-4 and IL-5. No such effect was observed in activated splenocytes derived from ovalbumin-primed mice (Cross et al. 1994a). Aedes aegypti and Cimex pipiens saliva, as well as sialokinin I purified from Aedes aegypti salivary glands (Fig. 3g), are able to down regulate IFN- $\gamma$ release and up-regulate IL-4 and IL-10 production up to 7 days after feeding (Zeidner et al. 1999). Recent data suggest that Aedes aegypti saliva can modify antigen-stimulated responses of transgenic OVA-TCR DO11 mouse splenocytes in vitro in a dose-dependent manner. An inhibition greater than $50 \%$ of T-cell proliferation was noted and the production of Th1 cytokines IL- 2 and IFN- $\gamma$, and pro-inflammatory cytokines GM-CSF and TNF- $\alpha$, and the Th2 cytokine IL-5, IL-4 and IL-10 were markedly reduced with a low-dose salivary stimulation (Wasserman et al. 2004). A protein of approximated $387 \mathrm{kDa}$ present in A. aegypti SGE reduced T-cell viability, whereas in dendritic cell it did not affect cell numbers but reduced its IL-12 production. Such profound effects observed with Aedes aegypti SGE are not observed with SGE from Culex quinquefasciatus (Wanasen et al. 2004), pointing out the different immunomodulatory activities used by these two culicine mosquitoes to take a successfully blood meal.

\section{B Cells and Antibody Production}

Ixodid ticks remain attached to their hosts and acquire a blood meal over a period ranging from days to weeks (Ribeiro 1989). The extended period of exposure to tick saliva provides ample opportunity for the host to develop acquired immune responses to those molecules, including antibody neutralization of immunogenic molecules. In fact, both natural and experimental hosts can develop immunologically-based resistance to tick feeding (Brossard and Wikel 1997, Wikel 1982, 1996). Acquired resistance to tick infestation is expressed as reduced engorgement, decreased numbers and viability of ova, impaired moulting, and death of feeding ticks (Wikel 1996, 1999b). To circumvent this life menace, ticks evolved different mechanisms for host antibody response suppression. Infestation of guinea pigs with adult $D$. andersoni reduced the IgM-attributable plaque-forming cell responses of the hosts after immunization with sheep erythrocytes (Wikel 1985), what suggests that tick feeding can suppress the host ability to generate primary antibody response to a thymic dependent antigen. Likewise, Rhi. sanguineus infestation of dogs reduced immunization-induced antibody responses even seven weeks after initial immunization (Inokuma et al. 1997). Ixodid ticks (Fig. 3i) also produce an unique family of proteins that bind vertebrate immunoglobulin (Wang and Nuttall 1995a, b), immunoglobulin-G binding proteins (IGBPs), discovered when it was realized that ticks excrete host immunoglobulins in their saliva during feeding (Wang and Nuttall 1994). Studies on the African tick (Wang and Nuttall 1994) Rhipicephalus appendiculatus, revealed that these immunoglobulins are transported from the tick body cavity to the salivary glands, whence they are excreted in the tick's saliva back into the host, retaining their antibodybinding activity. This led to the discovery of a family of IGBPs produced in the haemolymph and salivary glands of several ixodid tick species, either including Ixodes hexagonus and Amblyomma va- 
riegatum (Wang and Nuttall 1995b). Together these data indicated that IGBPs act as a self-defense system against ingested immunoglobulins.

Boophilus microplus ticks saliva can modulate the isotype of host antibody responses. High tick infestation decreases serum levels of $\mathrm{IgG} 1$ and IgG2 antibodies in susceptible (Holstein) breeds, but not in resistant (Nelore) ones. Conversely, levels of IgE antibodies increase after infestations in susceptible breeds, but are not related to protective anti-tick host response (Kashino et al. 2005).

Finally, the diversity of components mediating vertebrate inflammatory and haemostatic responses has been countered in evolution by an equally diverse array of antagonists in the saliva of bloodsucking arthropods.

\section{PATHOGEN DELIVERY: INTRUdERS TAKING A FREE RIDE}

The modifications on vertebrate host physiology caused by salivary active pharmacological molecules favors the delivery of microscopic parasites that colonize the digestive tract of the blood-feeding arthropod. This would apply to pathogens that are delivered via the mouthparts, either by salivation or regurgitation, and might also hold for those transmitted via rectum (e.g. Trypanosoma cruzi), since they may also invade the host through the bite wound (Titus and Ribeiro 1990). Indeed, the world's most important infectious diseases, ranging from malaria, filariasis, trypanosomiasis, leishmaniasis and Lyme diseases are transmitted by bloodsucking arthropods such as mosquitoes, tsetse flies, sand flies and ticks.

Titus and Ribeiro (Titus and Ribeiro 1988) first demonstrated that saliva of the sand fly Lutzomyia longipalpis enhanced Leishmania major infection when the parasite was co-inoculated with sand fly salivary gland lysate. In addition to enhancing lesion size, sand fly salivary gland lysate also markedly enhanced the parasite burden within the lesions. Similar findings were reported with other Leishmania species (Lima and Titus 1996, Samuelson et al.
1991, Theodos et al. 1991, Warburg et al. 1994). Maxadilan alone also exacerbated lesion size and parasite burden within the lesions to the same degree as sand fly salivary gland (Morris et al. 2001). Thus, maxadilan appear to be the principal peptide in the sand fly saliva that enhances infection with Leishmania major. PGE 2 , IL-4 and IL-6 also favor Leishmania establishment since the host immunoregulation can decrease the number of parasites been killed by activated immune cells. In leishmaniasis, resistance and protection are associated with the expression of IFN- $\gamma$ and IL-12 driving a CD4+ Th1 response, while susceptibility is linked to production of IL-4 and the development of a CD4+ Th2 response (Alexander et al. 1999, McSorley et al. 1996). Lutzomyia longipalpis saliva seems to drive, by an unknown mechanism, the host immune response to a Th2 type, less effective in terms of parasite clearance. Macrophages with suboptimal activation serve as reservoirs for Leishmania (Alexander et al. 1999, Solbach and Laskay 2000, Zer et al. 2001), where it can replicate without host control.

Saliva from $P$. duboscqi attracts vertebrate monocytes in vitro (Anjili et al. 1995) and saliva from $P$. papatasi not only attracts macrophages but also enhances infection by $L$. donovani in these cells, resulting in increased parasite loads (Zer et al. 2001). Interestingly, Lu. longipalpis saliva also induces CCL2/MCP-1 expression and macrophage recruitment to the inoculation site in the air pouch model of inflammation, possibly favoring Leishmania infection if these cells are not adequately activated (Teixeira CR, unpublished data). Despite the absence of maxadilan in its saliva, salivary gland lysates of Phlebotomus papatasi can also enhance infection with Leishmania, through induction of IL-4 production (Mbow et al. 1998). IL-4 exacerbates infection with Leishmania and can reduce parasite destruction by macrophages, reducing NO release (Mbow et al. 1998). The presence of adenosine in the salivary glands of Phlebotomus papatasi could also play a part in suppressing the immune 
responses and thus promoting the establishment of Leishmania parasites by enhancing production of IL-10 and, together with inosine, decreasing production of IL-12, IFN- $\gamma$, TNF- $\alpha$ and NO (Hasko et al. 1996, 1998, Romano et al. 1983).

Mosquitoes are associated with the transmission of malaria and many species of virus. Relationship between mosquitoes' saliva and the pathogens they transmit is largely neglected. These parasites colonize salivary glands and are naturally transmitted when a vector salivates during feeding a vertebrate host. For example, the Cache-Valley virus, an arthropod-borne bunyavirus, recently emerged as a significant veterinary pathogen causing infertility and congenital malformations in North America ruminants (Chung et al. 1990, Edwards et al. 2003, Edwards et al. 1989). Enhancement of infection by this virus on mice after feeding by Aedes triseriatus, Aedes aegypti or Culex pipiens, was observed but not elucidated (Edwards et al. 1998). Co-inoculation of sindbis virus with Aedes aegypti salivary gland extract resulted on a reduced IFN- $\beta$ expression, when compared to injection of virus alone (Schneider et al. 2004). Aedes aegypti can also transmit dengue virus, a flavivirus that causes dengue fever, dengue hemorrhagic fever and dengue shock syndrome. Dendritic cells seem to be permissive for dengue virus and function as primary targets of initial infection (Ader et al. 2004). Aedes aegypti saliva inhibited infection by dengue virus in DC, and pre-sensitization of DCs with saliva prior to infection enhanced inhibition. In addition, the proportion of dead cells was also reduced in virusinfected DC cultures exposed to mosquito saliva, and an enhanced production of IL-12p70 and TNF$\alpha$ was detected in these cultures (Ader et al. 2004). These data suggest a paradoxical protective role for Aedes aegypti saliva that limits viral uptake by DCs. However, more elucidative studies are needed for an overall understanding of the natural pathogenesis of dengue virus infection. Besides virus, Aedes saliva is also important in parasite transmission. Chickens subcutaneously infected with Plasmodium gal- linaceum sporozoites in the presence of Aedes fluviatillis SGH showed a higher level of parasitaemia when compared to those that received only sporozoites (Rocha et al. 2004). However, parasitaemia levels were lower among chickens immunized with SGH.

The influence of tick salivary components on parasite transmission has been studied intensively worldwide and shows us interesting data. In addition to Lyme disease, ticks are vectors of other pathogens that are responsible for rickettsial diseases (Burgdorfer 1977), babesiosis (Piesman et al. 1986, Spielman et al. 1985), emerging infections such as ehrlichiosis (Magnarelli et al. 1995, Telford et al. 1996), and may also transmit tick-borne encephalitis viruses (Telford et al. 1997), all of which may be influenced by tick salivary immunomodulatory factors. The etiological agent of Lyme disease, Borrelia burgdorferi, develops first in the midgut of the tick. It then migrates to the salivary glands when the tick is taking a blood meal and is injected with saliva into the vertebrate host (Ribeiro et al. 1987). A limited number of studies involving feeding Ixodes scapularis nymphs on mice have also been published, all utilizing ex vivo restimulation of splenocytes. Single (Zeidner et al. 1997) or repeated infestations with pathogen-free Ixodes scapularis nymphs resulted in suppression of the Th1 cytokines IL-2 and IFN- $\gamma$ and enhancement of the Th2 cytokines IL-4 and IL-10, (Schoeler et al. 1999). Zeidner et al. also took the additional approach of studying the effects of uninfected nymphs compared to nymphs infected with B. burgdorferi, thus allowing an assessment of the relative contribution of the vector and the pathogen to host immunomodulation. Using infected nymphs, they found that Th2 polarization occurred in $\mathrm{C} 3 \mathrm{H} / \mathrm{HeJ}$ mice but not in BALB/c mice after a single infestation, as assessed using splenocytes, and they suggested that this might have ramifications for spirochete transmission in vivo. Indeed, differences in susceptibility of hosts to tick feeding, and likewise pathogen transmission, may lie in relatively subtle 
differences in cytokine expression following exposure to tick salivary secretions and associated pathogens. The tick Dermacentor reticularis (Fig. 3f) can increase arboviruses transmission by affecting host NK cells functions and manipulating host cytokine network (Hajnicka et al. 2005), besides promoting virus growth (Hajnicka et al. 1998). It has been reported that tick saliva also enhances the transmission of Thogoto virus from infected to uninfected Rhipicephalus appendiculatus and Amblyomma variegatum ticks (Davies et al. 1990). The salivary effect observed was also seen even when the host did not exhibit detectable viraemia, and the virus was applied three days after saliva (Jones et al. 1987, 1990). Moreover, Rhipicephalus appendiculatus salivary gland extracts enhanced the uptake of Theileria parva sporozoites into lymphocytes, macrophages and afferent lymph veiled cells (Shaw et al. 1993).

\section{IMMUNE RESPONSE TO BLOOD-FEEDING SALIVARY GLAND ANTIGENS: THE COUNTER ATtACK}

All the effects of blood feeding arthropod saliva on host physiology observed here are originated from a unique molecule or a group of them. These molecules are also immunogenic and elicit host specific immune response. Thus, pre-exposure to insect saliva may render human and other vertebrate hosts resistant to a new blood meal or may even contribute to create an inhospitable environment for the establishment of the parasites transmitted by these insects. The observations regarding repeated exposure to pathogen-free ectoparasites and the subsequent development of resistance to vectorborne infections are intriguing. This knowledge can contribute to the development of a control strategy targeting the factors in blood-feeder saliva that are essential for the host immunossupression and the transmition of infectious agents.

Rabbits expressing acquired resistance to infestation with $D$. andersoni are less susceptible to infection with tick-transmitted Franciella tularesis than tick susceptible controls. Subsequent studies supported evidence that pre-exposure to tick's bites may induce host resistance. Guinea pigs that are resistant and form a DTH response in the area of saliva from Rhipicephalus sanguineus inoculation are more resistant to future tick infestations while dogs and mice that develop an immediate response with a disturbed pattern of cellular migration are susceptible to infestations (Ferreira et al. 2003). Mice infested four times with pathogen-free Ixodes scapularis developed acquired resistance to Borrelia burgdorferi infection in subsequent challenge with infected ticks (Wikel et al. 1997). A similar study with guinea pigs exposed previously to uninfected Ixodes scapularis showed that repeated challenges lead to a development of host tick immunity and protection against Borrelia burgdorferi (Nazario et al. 1998). The host's specific antibody production against ticks was also used as epidemiological marker of previous vector exposure, such as to Ixodes scapularis (Schwartz et al. 1990, 1991).

More recently, the protective host response was reported in sand flies (Belkaid et al. 1998). The exacerbative effect of saliva on infection, seen when mice were co-inoculated with $L$. major and salivary glands sonicate (SGS) of P. papatasi, was completely abrogated in mice pre-exposed to the salivary sonicate (Belkaid et al. 1998). This protection was reproduced following transmission of $L$. major by the bite of infective P. papatasi sand flies. Compared with naïve mice, mice pre-exposed to the bites of uninfected flies showed reduction in lesion pathology, in parasite load, and also in their ability to transmit Leishmania back to uninfected flies (Kamhawi et al. 2000). The protection conferred by pre-exposure of mice to saliva was associated with a strong DTH response at the site of the bite (Kamhawi et al. 2000). We have demonstrated that $L u$. longipalpis saliva induces an intense and diffuse inflammatory infiltrate characterized by neutrophils, eosinophils, and macrophages in pre-exposed mice. This response was observed at 2 hours and sustained up to 48 hours after SGS challenge, but was not a typical 
DTH reaction, which is predominantly a mononuclear cell infiltrate. Two hours after injection of immune sera preincubated with SGS in the ear dermis of unexposed mice, there was an inflammatory infiltrate comprised of neutrophils and macrophages, suggesting a potential role of immune complexes in the observed cell infiltration (Silva et al. 2005).

$\mathrm{BALB} / \mathrm{c}$ mice exposed to repeated $L u$. longipalpis bites developed antibodies to saliva. Significant IgG and IgG1 anti-saliva antibody responses were elicited, which suggest a predominant Th2 response in these animals. Sera from immune mice recognized with a high frequency and a strong reaction the $45-\mathrm{kD}$ and $44-\mathrm{kD}$ proteins from $\mathrm{Lu}$. longipalpis saliva (Silva et al. 2005). These proteins were also the major targets of human antibody response in an endemic area (Barral et al. 2000). Since these proteins are widely recognized, they are natural candidates to be used as markers of exposure to $L u$. longipalpis bites. Mounting an antibody response against sand fly saliva occurred at the same time as the host developed an anti-leishmania cell-mediated immune response (Gomes et al. 2002). Although tempting, it remains to be demonstrated that protection against Leishmania infections is conferred by pre-exposure to sand fly bites in endemic areas for leishmaniasis.

Anopheles stephensi mosquito bites induce dermal mast cell degranulation, leading to fluid extravasation and neutrophil influx (Demeure et al. 2005). This inflammatory response does not occur in mast cell-deficient $\mathrm{W} / \mathrm{Wv}$ mice, unless these are reconstituted specifically with mast cells. Mast cell activation caused by $A$. stephensi mosquito bites is followed by hyperplasia of the draining lymph node due to the accumulation of $\mathrm{CD}^{+}, \mathrm{B} 220^{+}, \mathrm{CD} 11 \mathrm{~b}^{+}$, and $\mathrm{CD} 11 \mathrm{c}^{+}$leukocytes. The $\mathrm{T}$ cell enrichment of the draining lymph nodes results from their sequestration from the circulation rather than local proliferation (Demeure et al. 2005). This work emphasized the critical contribution of peripheral mast cells in inducing $\mathrm{T}$ cell and dendritic cell recruitment within draining lymph nodes, a prerequisite for the elicita- tion of T and B lymphocyte priming. There was also a slight increase in mast cells present in the ear dermis of mice two hours after Lutzomyia longipalpis bites (Silva et al. 2005).

Mice immunized with salivary antigens from Simulium vittatum developed IgG, IgM, and IgE antibodies which recognized several salivary gland components. Sera from bitten mice recognized fewer antigens than sera from animals intraperitoneally immunized with salivary gland extract, indicating that some components of the salivary gland extract were poorly immunogenic or absent from the saliva secreted during blood-feeding (Cross et al. 1993b).

These data suggest that human and others vertebrate hosts can develop immune responses that block the effects of saliva and that an appropriate vaccine should accelerate the development of these responses in the vaccinated host and thus protect against vector-borne infections. But the development of vector-blocking vaccines will not be a trivial task.

\section{CLOSING REMARKS}

The key for the success of blood-feeding arthropod parasitism is the ability of avoiding host immune responses through the production of specific salivary antagonists. Analyzes of these substances reveal a significant biochemical and pharmacological diversity. The isolation of specific molecules through experimental techniques has been made over the last 10 years and contribute to a better understanding of pathogen-vector-host interactions. Although many aspects have been described a few important issues remain to be understood to better explore salivary molecules.

Haematophagy has a polyphyletic origin, but a convergent evolution has equipped many haematophagous animals, with analogous resources for the success blood meal, not only between insects, but even in bats, worms, and leeches. The variation in salivary content has been described among the same species in different geographical regions. 
An expanded effort for studying salivary content of species from different parts of the world will certainly increase the chances in finding common molecules that could function as markers or as candidates for a wide-ranging vaccine. The identification of new species or subspecies may also reveal novel molecules or strategies in avoiding host defense mechanism. This natural diversity of substances can serve in therapeutics and biomedical research but a note of caution is necessary as salivary products have diverse behavior in distinct models of inflammation or immune response. Understanding such variation, as well as testing the same molecule in several models, is important for unraveling subtle differences in composition and molecular interaction with potential practical applications. There is also a need in expanding our understanding of host protective mechanisms. Some aspects remain under explored, few studies exist on the interaction of salivary products and innate immunity, e.g. The aspects involved in future adaptive immune response resulting in resistance or susceptibility widely depends on the first attempt of host's innate response to contain infection/infestation that may influence on the predominance of a pattern of future host's immune adaptative response.

The ultimate purpose of research that examines pathogens transmitted by arthropods is to develop an effective vaccine. But it has proven very difficult to develop efficiently host sterile immunity and long-lived vaccines against vector-borne pathogen and parasites. These organisms often present very complex life cycles, enabling the occurrence of new and more pathogenic strains also resistant to conventional treatment. Vaccines that target more than one facet of parasite's life cycle, like the pathogen itself, vector salivary proteins and vector-pathogen interactions, may prove to be more effective, but more resources are needed to improve this knowledge. New genetic sequencing technologies and high efficient proceedings of protein isolation and cloning permit the experimental production of some of these substances indispensable for biochemical, pharmacological and immunological investigations and even for clinical studies.

High-throughput genomic and proteomic approaches for cloning salivary cDNA have resulted in the discovery of genes and proteins not previously reported in blood feeding arthropods. These reality allows not only the isolation of salivary factors implicated in host hemostasis and inflammation, but also the characterization of novel salivary molecules, for many of which the biological function is unknown (Valenzuela 2001). Within this huge quantity of molecules, those responsible for the salivary modulatory effects on their hosts, which also permit the vector-borne pathogen establishment, may be targeted by an ideal vaccine. The challenge is to encounter a high-throughput expression system to test the biological activities of each candidate molecule. Such perspectives are summarized in Table I.

Thus, for vaccination using vector salivary proteins, the isolation of salivary immunossuppressors to make specific neutralizing antibodies and the pursuit of salivary proteins that elicit optimal cellular responses are strategies that if combined may result in reducing disease burden, rewriting this tale of blood, albeit may not reduce the host tissue tear.

\section{RESUMO}

A saliva de artrópodes hematófagos é rica em moléculas com funções diversas que mediam uma alimentação sangüínea bem sucedida. Estas moléculas agem não apenas como armas contra a resposta hemostática, inflamatória e imunológica do hospedeiro funcionando também como ferramentas para o estabelecimento de patógenos. Parasitas, vírus e bactérias aproveitando-se deste arsenal dos vetores adaptaram-se facilitando seu estabelecimento no hospedeiro. Hoje, várias moléculas salivares foram identificadas e caracterizadas como novos alvos para o desenvolvimento de vacinas futuras. Neste trabalho, centramos em informação recente sobre a saliva de vetores e as moléculas responsáveis por modificar a resposta hemostática e imunológica assim como seu papel na transmissão de doenças. 
TABLE I

Future challenges regarding saliva from haematophagous vectors.

- Identification of new species or subspecies to reveal

a wider option of molecules that impair host's defense mechanisms;

- Salivary molecules isolation trough new genetic sequencing technologies and high efficient proceedings facilitating the access to study candidate molecules;

- Identify salivary content of species worldwide targeting common molecules from sibling species for a wide-ranging vaccine;

- Understand protective mechanisms regarding the early steps of host's response to salivary molecules that can lead to resistance or susceptibility;

- Test candidate salivary molecules in several models for enlightening subtle differences and similarities within components important for pathogen establishment;

- Development of vaccines that target aspects of pathogens and salivary molecules simultaneously.

Palavras-chave: saliva, picadas, hemostasia, hospedeiro, vetor, infecção.

\section{REFERENCES}

Ader DB, Celluzzi C, Bisbing J, Gilmore L, Gunther V, PEACHMAN KK, RAO M, BARVIR D, SUN W AND PALMER DR. 2004. Modulation of dengue virus infection of dendritic cells by Aedes aegypti saliva. Viral Immunol 17: 252-265.

Alexander J, Satoskar AR And Russell DG. 1999. Leishmania species: models of intracellular parasitism. J Cell Sci 112: 2993-3002.

AleXANDER JO. 1986. The physiology of itch. Parasitol Today 2: 345-351.

Anjili CO, Mbati PA, Mwangi RW, Githure Ji, Olobo JO, Robert LL AND KoECH DK. 1995. The chemotactic effect of Phlebotomus duboscqi (Diptera: Psychodidae) salivary gland lysates to murine monocytes. Acta Trop 60: 97-100.

Arca B, Lombardo F, DE LARA CAPUrRo M, DELLA TORRE A, Dimopoulos G, JAMES AA AND ColuzzI M. 1999. Trapping cDNAs encoding secreted proteins from the salivary glands of the malaria vector Anopheles gambiae. Proc Natl Acad Sci USA 96: 1516-1521.
Bahl AK, Foreman JC and Dale MM. 1991. The effect of prostaglandin E2 and non-steroidal antiinflammatory drugs on cell-associated interleukin one. Adv Prostaglandin Thromboxane Leukot Res 21B: 513-515.

Barral A, Honda E, Caldas A, Costa J, Vinhas V, Rowton ED, Valenzuela JG, Charlab R, BARRAL-NetTo M ANd Ribeiro JM. 2000. Human immune response to sand fly salivary gland antigens: a useful epidemiological marker? Am J Trop Med Hyg 62: 740-745.

Belkaid Y, Kamhawi S, Modi G, Valenzuela J, Noben-Trauth N, Rowton E, Ribeiro J And SACKS DL. 1998. Development of a natural model of cutaneous leishmaniasis: powerful effects of vector saliva and saliva preexposure on the long-term outcome of Leishmania major infection in the mouse ear dermis. J Exp Med 188: 1941-1953.

Belkaid Y, Valenzuela JG, Kamhawi S, RowTON E, SACKS DL AND RIBEIRo JM. 2000. Delayed-type hypersensitivity to Phlebotomus papatasi sand fly bite: An adaptive response induced by the fly? Proc Natl Acad Sci USA 97: 6704-6709.

Bell JF, STEWART SJ AND WiKel SK. 1979. Resistance to tick-borne Francisella tularensis by tick- 
sensitized rabbits: allergic klendusity. Am J Trop Med Hyg 28: 876-880.

BERGMAN DK, RAMAChandRA RN AND WIKEL SK. 1995. Dermacentor andersoni: salivary gland proteins suppressing T-lymphocyte responses to concanavalin A in vitro. Exp Parasitol 81: 262-271.

BERGMAN DK, RAMACHANDRA RN AND WIKEL SK. 1998. Characterization of an immunosuppressant protein from Dermacentor andersoni (Acari: Ixodidae) salivary glands. J Med Entomol 35: 505-509.

BissonnetTe EY, Rossignol PA AND Befus AD. 1993. Extracts of mosquito salivary gland inhibit tumour necrosis factor alpha release from mast cells. Parasite Immunol 15: 27-33.

Boyce JA. 2004. The biology of the mast cell. Allergy Asthma Proc 25: 27-30.

Bozza M, SoARES MB, Bozza PT, SATOSKAR AR, Diacovo TG, Brombacher F, Titus RG, ShoEmaker CB AND DAVID JR. 1998. The PACAP-type I receptor agonist maxadilan from sand fly saliva protects mice against lethal endotoxemia by a mechanism partially dependent on IL-10. Eur J Immunol 28: 3120-3127.

BROSSARD M AND WIKEL SK. 1997. Immunology of interactions between ticks and hosts. Med Vet Entomol 11: 270-276.

BRUMMER-KORVENKONTIO H, LAPPALAINEN P, REunala T and Palosuo T. 1994. Detection of mosquito saliva-specific IgE and IgG4 antibodies by immunoblotting. J Allergy Clin Immunol 93: 551-555.

BURGDORFER W. 1977. Tick-borne diseases in the United States: Rocky Mountain spotted fever and Colorado tick fever. A review. Acta Trop 34: 103126.

Cappello M, Bergum PW, Vlasuk GP, Furmidge BA, PRITChARD DI AND AKsoy S. 1996. Isolation and characterization of the tsetse thrombin inhibitor: a potent antithrombotic peptide from the saliva of Glossina morsitans morsitans. Am J Trop Med Hyg 54: 475-480.

Cappello M, li S, Chen X, li CB, Harrison L, NARASHIMHAN S, BEARD CB AND AKSOY S. 1998. Tsetse thrombin inhibitor: bloodmeal-induced expression of an anticoagulant in salivary glands and gut tissue of Glossina morsitans morsitans. Proc Natl Acad Sci USA 95: 14290-14295.

CaValcante RR, Pereira MH And Gontijo NF. 2003. Anti-complement activity in the saliva of phlebotomine sand flies and other haematophagous insects. Parasitology 127: 87-93.

Cavassani KA, Aliberti JC, Dias AR, Silva JS AND FERREIRA BR. 2005. Tick saliva inhibits differentiation, maturation and function of murine bonemarrow-derived dendritic cells. Immunology 114: 235-245.

Champagne DE. 1994. The role of salivary vasodilators in bloodfeeding and parasite transmission. Parasitol Today 10: 430-433.

Champagne DE AND Ribeiro JM. 1994. Sialokinin I and II: vasodilatory tachykinins from the yellow fever mosquito Aedes aegypti. Proc Natl Acad Sci USA 91: $138-142$.

Champagne DE, Nussenzveig RH AND Ribeiro JM. 1995a. Purification, partial characterization, and cloning of nitric oxide-carrying heme proteins (nitrophorins) from salivary glands of the bloodsucking insect Rhodnius prolixus. J Biol Chem 270: 8691-8695.

Champagne DE, SMARTt CT, Ribeiro JM AND JAMES AA. 1995b. The salivary gland-specific apyrase of the mosquito Aedes aegypti is a member of the 5'-nucleotidase family. Proc Natl Acad Sci USA 92: 694-698.

Charlab R, Valenzuela JG, Rowton ED And RIBEIRO JM. 1999. Toward an understanding of the biochemical and pharmacological complexity of the saliva of a hematophagous sand fly Lutzomyia longipalpis. Proc Natl Acad Sci USA 96: 1515515160.

Charlab R, Rowton ED And Ribeiro JM. 2000. The salivary adenosine deaminase from the sand fly Lutzomyia longipalpis. Exp Parasitol 95: 45-53.

Chinery WA AND AyiteY-SMith E. 1977. Histamine blocking agent in the salivary gland homogenate of the tick Rhipicephalus sanguineus sanguineus. Nature 265: 366-367.

Chung Si, Livingston CW-Jr., Edwards JF, 
Crandell RW, Shope RE, Shelton MJ And Collisson EW. 1990. Evidence that Cache Valley virus induces congenital malformations in sheep. Vet Microbiol 21: 297-307.

CLARK WG. 1979. Kinins and the peripheral and central nervous systems. Handbook of Experimental Pharmacology 25: 311-356.

Collis MG. 1989. The vasodilator role of adenosine. Pharmacol Ther 41: 143-162.

COSTA DJ ET AL. 2004. Lutzomyia longipalpis salivary gland homogenate impairs cytokine production and costimulatory molecule expression on human monocytes and dendritic cells. Infect Immun 72: 1298 1305.

Cross Ml, Cupp MS, Cupp EW, Galloway AL AND ENRIQUEZ FJ. 1993a. Modulation of murine immunological responses by salivary gland extract of Simulium vittatum (Diptera: Simuliidae). J Med Entomol 30: 928-935.

Cross ML, Cupp MS, Cupp EW, RAmberg FB AND ENRIQUEZ FJ. 1993b. Antibody responses of $\mathrm{BALB} / \mathrm{c}$ mice to salivary antigens of hematophagous black flies (Diptera: Simuliidae). J Med Entomol 30: 725-734.

Cross ML, Cupp EW AND EnRIQUeZ FJ. 1994a. Differential modulation of murine cellular immune responses by salivary gland extract of Aedes aegypti. Am J Trop Med Hyg 51: 690-696.

Cross ML, Cupp EW ANd EnriQuez FJ. 1994b. Modulation of murine cellular immune responses and cytokines by salivary gland extract of the black fly Simulium vittatum. Trop Med Parasitol 45: 119-124.

CupP MS, RibeIRo JM AND CUPP EW. 1994. Vasodilative activity in black fly salivary glands. Am J Trop Med Hyg 50: 241-246.

CUPP MS, Ribeiro JM, CHAMPAGNE DE AND CUPP EW. 1998. Analyses of cDNA and recombinant protein for a potent vasoactive protein in saliva of a blood-feeding black fly, Simulium vittatum. J Exp Biol 201: 1553-1561.

Dan A, Pereira MH, Pesquero JL, Diotaiuti L AND BEIRAO PS. 1999. Action of the saliva of Triatoma infestans (Heteroptera: Reduviidae) on sodium channels. J Med Entomol 36: 875-879.
DAVIES CR, Jones LD AND NutTall PA. 1990. A comparative study of the infection thresholds of Thogoto virus in Rhipicephalus appendiculatus and Amblyomma variegatum. Am J Trop Med Hyg 43: 99-103.

Delves PJ AND RoITt IM. 2000. The immune system. First of two parts. N Engl J Med 343: 37-49.

Demeure CE ET AL. 2005. Anopheles mosquito bites activate cutaneous mast cells leading to a local inflammatory response and lymph node hyperplasia. J Immunol 174: 3932-3940.

Dickinson RG, O'HAGAN JE, SCHOTZ M, BINNington KC AND Hegarty MP. 1976. Prostaglandin in the saliva of the cattle tick Boophilus microplus. Aust J Exp Biol Med Sci 54: 475-486.

DionisotTi S, Zocchi C, VARANi K, BoREA PA AND ONGINI E. 1992. Effects of adenosine derivatives on human and rabbit platelet aggregation. Correlation of adenosine receptor affinities and antiaggregatory activity. Naunyn Schmiedebergs Arch Pharmacol 346: 673-676.

Dusbabek F, Borsky I, Jelinek F AND Uhlir J. 1995. Immunosuppression and feeding success of Ixodes ricinus nymphs on BALB/c mice. Med Vet Entomol 9: 133-140.

Edwards JF, Livingston CW, ChUng SI AND COLlisson EC. 1989. Ovine arthrogryposis and central nervous system malformations associated with in utero Cache Valley virus infection: spontaneous disease. Vet Pathol 26: 33-39.

Edwards JF, Higgs S And Beaty BJ. 1998. Mosquito feeding-induced enhancement of Cache Valley Virus (Bunyaviridae) infection in mice. J Med Entomol 35: 261-265.

Edwards JF, Angulo AB And Pannill EC. 2003. Theriogenology question of the month. In utero infection of the doe by CVV. J Am Vet Med Assoc 222: 1361-1362.

FAUdRY E, LOZZI SP, SANTANA JM, D'SOUZA-AULT M, KiefFer S, Felix CR, Ricart CA, SOUSA MV, VERnet T AND TEIXEIRA AR. 2004. Triatoma infestans apyrases belong to the 5'-nucleotidase family. J Biol Chem 279: 19607-19613.

Feingold BF And Benjamini E. 1961. Allergy to 
flea bites. Clinical and experimental observations. Ann Allergy 19: 1275-1289.

FERREIRA BR AND SILVA JS. 1998. Saliva of Rhipicephalus sanguineus tick impairs $\mathrm{T}$ cell proliferation and IFN-gamma-induced macrophage microbicidal activity. Vet Immunol Immunopathol 64: 279-293.

FERREIRA BR AND SILVA JS. 1999. Successive tick infestations selectively promote a T-helper 2 cytokine profile in mice. Immunology 96: 434-439.

Ferreira BR, Szabo MJ, CaVAsSani KA, BechaRA GH AND SILVA JS. 2003. Antigens from Rhipicephalus sanguineus ticks elicit potent cell-mediated immune responses in resistant but not in susceptible animals. Vet Parasitol 115: 35-48.

Francischetti IM, Ribeiro JM, Champagne D And Andersen J. 2000. Purification, cloning, expression, and mechanism of action of a novel platelet aggregation inhibitor from the salivary gland of the blood-sucking bug, Rhodnius prolixus. J Biol Chem 275: 12639-12650.

Francischetti IM, VALENZUela JG, ANDERSEN JF, MATHER TN AND RiBEIRo JM. 2002. Ixolaris, a novel recombinant tissue factor pathway inhibitor (TFPI) from the salivary gland of the tick, Ixodes scapularis: identification of factor $\mathrm{X}$ and factor $\mathrm{Xa}$ as scaffolds for the inhibition of factor VIIa/tissue factor complex. Blood 99: 3602-3612.

FUCHSBERGER N, KitA M, HAJNiCKA V, IMANISHI J, Labuda M AND NutTall PA. 1995. Ixodid tick salivary gland extracts inhibit production of lipopolysaccharide-induced mRNA of several different human cytokines. Exp Appl Acarol 19: 671-676.

Fuentes-Prior P, Noeske-Jungblut C, Donner $\mathrm{P}$, Schleuning WD, Huber R ANd Bode W. 1997. Structure of the thrombin complex with triabin, a lipocalin-like exosite-binding inhibitor derived from a triatomine bug. Proc Natl Acad Sci USA 94: 11845-11850.

Gillespie RD, Mbow ML and Titus RG. 2000. The immunomodulatory factors of bloodfeeding arthropod saliva. Parasite Immunol 22: 319-331.

Gillespie RD, Dolan MC, Piesman And Titus RG. 2001. Identification of an IL-2 binding protein in the saliva of the Lyme disease vector tick, Ixodes scapularis. J Immunol 166: 4319-4326.
Gomes RB, Brodskyn C, De Oliveira Ci, Costa J, Miranda JC, Caldas A, Valenzuela JG, BArRal-NetTo M ANd BARral A. 2002. Seroconversion against Lutzomyia longipalpis saliva concurrent with the development of anti-Leishmania chagasi delayed-type hypersensitivity. J Infect Dis 186: 1530-1534.

Grevelink SA, Youssef DE, Loscalzo J And LERNER EA. 1993. Salivary gland extracts from the deerfly contain a potent inhibitor of platelet aggregation. Proc Natl Acad Sci USA 90: 9155-9158.

Grevelink SA, Osborne J, Loscalzo J AND LERNER EA. 1995. Vasorelaxant and second messenger effects of maxadilan. J Pharmacol Exp Ther 272: 33-37.

GUBLER DJ. 1998. Resurgent vector-borne diseases as a global health problem. Emerg Infect Dis 4: 442-450.

Hajnicka V, Fuchsberger N, Slovak M, KocaKova P, Labuda M and Nuttall PA. 1998. Tick salivary gland extracts promote virus growth in vitro. Parasitology 116: 533-538.

HaJNicka V, VANCOVA I, KocaKova P, SlovaK M, GASPERIK J, SLAVIKOVA M, Hails RS, LABUdA M AND NutTAll PA. 2005. Manipulation of host cytokine network by ticks: a potential gateway for pathogen transmission. Parasitology 130: 333-342.

HALl LR AND Titus RG. 1995. Sand fly vector saliva selectively modulates macrophage functions that inhibit killing of Leishmania major and nitric oxide production. J Immunol 155: 3501-3506.

Hasko G, Szabo C, Nemeth ZH, Kvetan V, PaSTORES SM AND VIZI ES. 1996. Adenosine receptor agonists differentially regulate IL-10, TNFalpha, and nitric oxide production in RAW 264.7 macrophages and in endotoxemic mice. J Immunol 157: 4634-4640.

Hasko G, Nemeth ZH, Vizi ES, Salzman AL AND SzABo C. 1998. An agonist of adenosine A3 receptors decreases interleukin-12 and interferongamma production and prevents lethality in endotoxemic mice. Eur J Pharmacol 358: 261-268.

Hasko G, Kuhel DG, Nemeth ZH, Mabley JG, Stachlewitz RF, Virag L, Lohinai Z, Southan GJ, Salzman AL and Szabo C. 2000. Inosine inhibits inflammatory cytokine pro- 
duction by a posttranscriptional mechanism and protects against endotoxin-induced shock. J Immunol 164: 1013-1019.

Higgs GA, VAne JR, Hart RJ, Porter C And WilSON RG. 1976. Prostaglandins in the saliva of the cattle tick, Boophilus microplus (Canestrini) (Acarina, Ixodidae). Bull Entomol Res 66: 665-670.

Horn F, dos SAntos PC AND TERMignoni C. 2000. Boophilus microplus anticoagulant protein: an antithrombin inhibitor isolated from the cattle tick saliva. Arch Biochem Biophys 384: 68-73.

INOKUMA H, KEMP DH AND WILLADSEN P. 1994. Prostaglandin E2 production by the cattle tick (Boophilus microplus) into feeding sites and its effect on the response of bovine mononuclear cells to mitogen. Vet Parasitol 53: 293-299.

InOKuma H, Aita T, TAMURA K AND ONIShi T. 1997. Effect of infestation with Rhipicephalus sanguineus on the antibody productivity in dogs. Med Vet Entomol 11: 201-202.

Jones LD, Davies CR, Steele GM ANd Nuttall PA. 1987. A novel mode of arbovirus transmission involving a nonviremic host. Science 237: 775-777.

JONES LD, DAVIES CR, WILliams T, CORY J AND NutTALL PA. 1990. Non-viraemic transmission of Thogoto virus: vector efficiency of Rhipicephalus appendiculatus and Amblyomma variegatum. Trans R Soc Trop Med Hyg 84: 846-848.

Jones LD, Kaufman WR AND NutTall PA. 1992. Modification of the skin feeding site by tick saliva mediates virus transmission. Experientia 48: 779782.

Kalvachova P, Hribalova V, Kodym P and Volf P. 1999. Modulation of murine lymphocyte responsiveness by the saliva of Rhodnius prolixus (Hemiptera: Reduviidae). J Med Entomol 36: 341-344.

KAMHAWI S. 2000. The biological and immunomodulatory properties of sand fly saliva and its role in the establishment of Leishmania infections. Microbes Infect 2: 1765-1773.

KAMHawi S, Belkaid Y, Modi G, Rowton E AND SACKS D. 2000. Protection against cutaneous leishmaniasis resulting from bites of uninfected sand flies. Science 290: 1351-1354.
KASHINO SS ET AL. 2005. Boophilus microplus: the pattern of bovine immunoglobulin isotype responses to high and low tick infestations. Exp Parasitol 110: $12-21$.

Katz O, Waitumbi JN, Zer R and Warburg A. 2000. Adenosine, AMP, and protein phosphatase activity in sandfly saliva. Am J Trop Med Hyg 62: 145-150.

Kopecky J AND KutheJlova M. 1998. Suppressive effect of Ixodes ricinus salivary gland extract on mechanisms of natural immunity in vitro. Parasite Immunol 20: 169-174.

Kubes M, Kocakova P, Slovak M, Slavikova M, Fuchsberger N AND NutTall PA. 2002. Heterogeneity in the effect of different ixodid tick species on human natural killer cell activity. Parasite Immunol 24: 23-28.

Lanzaro GC, Lopes AH, Ribeiro JM, ShoeMaker CB, Warburg A, SoAres M ANd Titus RG. 1999. Variation in the salivary peptide, maxadilan, from species in the Lutzomyia longipalpis complex. Insect Mol Biol 8: 267-275.

LAVOIPIERRE MM. 1965. Feeding mechanism of bloodsucking arthropods. Nature 208: 302-303.

Le Moine O, Stordeur P, Schandene L, MarCHANT A, DE GRoote D, Goldman M AND DEVIERE J. 1996. Adenosine enhances IL-10 secretion by human monocytes. J Immunol 156: 44084414.

LERNer EA AND ShoemaKer CB. 1992. Maxadilan. Cloning and functional expression of the gene encoding this potent vasodilator peptide. J Biol Chem 267: 1062-1066.

LERNER EA, RIBEIRO JM, NELSON RJ AND LERNER MR. 1991. Isolation of maxadilan, a potent vasodilatory peptide from the salivary glands of the sand fly Lutzomyia longipalpis. J Biol Chem 266: 1123411236.

Lewis CD, Hourani SM, Long CJ And Collis MG. 1994. Characterization of adenosine receptors in the rat isolated aorta. Gen Pharmacol 25: 13811387.

Lima HC AND Titus RG. 1996. Effects of sand fly vector saliva on development of cutaneous lesions 
and the immune response to Leishmania braziliensis in BALB/c mice. Infect Immun 64: 5442-5445.

Link AA, Kino T, Worth JA, MCGuire JL, CrAne ML, Chrousos GP, Wilder RL AND ElENKov IJ. 2000. Ligand-activation of the adenosine A2a receptors inhibits IL-12 production by human monocytes. J Immunol 164: 436-442.

Macaluso KR And WiKel SK. 2001. Dermacentor andersoni: effects of repeated infestations on lymphocyte proliferation, cytokine production, and adhesion-molecule expression by BALB/c mice. Ann Trop Med Parasitol 95: 413-427.

Magnarelli LA, Dumler JS, Anderson JF, JOHNSON RC AND FIKRIG E. 1995. Coexistence of antibodies to tick-borne pathogens of babesiosis, ehrlichiosis, and Lyme borreliosis in human sera. J Clin Microbiol 33: 3054-3057.

Mbow ML, Bleyenberg JA, Hall LR and Titus RG. 1998. Phlebotomus papatasi sand fly salivary gland lysate down-regulates a Th1, but up-regulates a Th2, response in mice infected with Leishmania major. J Immunol 161: 5571-5577.

MCSORley S, Proudfoot L, O'Donnell CA AND LIEW FY. 1996. Immunology of murine leishmaniasis. Clin Dermatol 14: 451-464.

Moro O AND LERNER EA. 1997. Maxadilan, the vasodilator from sand flies, is a specific pituitary adenylate cyclase activating peptide type I receptor agonist. J Biol Chem 272: 966-970.

Moro O, Tajima M and Lerner EA. 1996. Receptors for the vasodilator maxadilan are expressed on selected neural crest and smooth muscle-derived cells. Insect Biochem Mol Biol 26: 1019-1025.

Morris RV, SHOEMAKer CB, DAVID JR, LANZARo GC AND Titus RG. 2001. Sandfly maxadilan exacerbates infection with Leishmania major and vaccinating against it protects against L. major infection. J Immunol 167: 5226-5230.

NASCIMENTO EP, DOS SANTOS MALAFRONTE R AND MARINOTTI O. 2000. Salivary gland proteins of the mosquito Culex quinquefasciatus. Arch Insect Biochem Physiol 43: 9-15.

Nazario S, Das S, de Silva AM, Deponte K, Marcantonio N, Anderson JF, Fish D, FI-
KRIG E AND KANTOR FS. 1998. Prevention of Borrelia burgdorferi transmission in guinea pigs by tick immunity. Am J Trop Med Hyg 58: 780-785.

Noeske-Jungblut C, Kratzschmar J, HaendLer B, Alagon A, Possani L, Verhallen P, DonNer P AND SCHLEUning WD. 1994. An inhibitor of collagen-induced platelet aggregation from the saliva of Triatoma pallidipennis. J Biol Chem 269: 5050-5053.

Noeske-Jungblut C, Haendler B, Donner P, Alagon A, Possani L and Schleuning WD. 1995. Triabin, a highly potent exosite inhibitor of thrombin. J Biol Chem 270: 28629-28634.

Paesen GC, Adams Pl, Harlos K, Nuttall PA AND STUART DI. 1999. Tick histamine-binding proteins: isolation, cloning, and three-dimensional structure. Mol Cell 3: 661-671.

Pereira MH, Souza Me, Vargas AP, Martins MS, Penido CM and Diotaiuti L. 1996. Anticoagulant activity of Triatoma infestans and Panstrongylus megistus saliva (Hemiptera/Triatominae). Acta Trop 61: 255-261.

Perez de Leon AA, Ribeiro JM, TABAChNick WJ AND VALENZUELA JG. 1997. Identification of a salivary vasodilator in the primary North American vector of bluetongue viruses, Culicoides variipennis. Am J Trop Med Hyg 57: 375-381.

Phipps RP, STEIN SH AND Roper RL. 1991. A new view of prostaglandin $\mathrm{E}$ regulation of the immune response. Immunol Today 12: 349-352.

Piesman J, Mather TN, Telford SR-3Rd AND SPIElman A. 1986. Concurrent Borrelia burgdorferi and Babesia microti infection in nymphal Ixodes dammini. J Clin Microbiol 24: 446-447.

Qureshi AA, Asahina A, OHNUmA M, TAJima M, Granstein RD AND Lerner EA. 1996. Immunomodulatory properties of maxadilan, the vasodilator peptide from sand fly salivary gland extracts. Am J Trop Med Hyg 54: 665-671.

RAMACHANDRA RN AND WIKEL SK. 1992. Modulation of host-immune responses by ticks (Acari: Ixodidae): effect of salivary gland extracts on host macrophages and lymphocyte cytokine production. J Med Entomol 29: 818-826. 
RAMACHANDRA RN AND WIKEL SK. 1995. Effects of Dermacentor andersoni (Acari: Ixodidae) salivary gland extracts on Bos indicus and B. taurus lymphocytes and macrophages: in vitro cytokine elaboration and lymphocyte blastogenesis. J Med Entomol 32: 338-345.

Reunala T, Brummer-Korvenkontio H, Palosuo K, Miyanij M, Ruiz-Maldonado R, Love A, Francois G and Palosuo T. 1994. Frequent occurrence of $\mathrm{IgE}$ and $\mathrm{IgG} 4$ antibodies against saliva of Aedes communis and Aedes aegypti mosquitoes in children. Int Arch Allergy Immunol 104: 366-371.

RIBEIRO JM. 1987a. Ixodes dammini: salivary anticomplement activity. Exp Parasitol 64: 347-353.

RIBEIRO JM. 1987b. Role of saliva in blood-feeding by arthropods. Annu Rev Entomol 32: 463-478.

RIBEIRO JM. 1987c. Vector salivation and parasite transmission. Mem Inst Oswaldo Cruz 82(Suppl. 3): 1-3.

RIBEIRO JM. 1989. Role of saliva in tick/host interactions. Exp Appl Acarol 7: 15-20.

RIBEIRO JM. 1995a. Blood-feeding arthropods: live syringes or invertebrate pharmacologists? Infect Agents Dis 4: 143-152.

Ribeiro JM. 1995b. How ticks make a living. Parasitol Today 11: 91-93.

RIBEIRO JM AND FRANCISCHETTI IM. 2003. Role of arthropod saliva in blood feeding: sialome and postsialome perspectives. Annu Rev Entomol 48: 73-88.

RIBEIRO JM AND MATHER TN. 1998. Ixodes scapularis: salivary kininase activity is a metallo dipeptidyl carboxypeptidase. Exp Parasitol 89: 213-221.

Ribeiro JM AND Modi G. 2001. The salivary adenosine/AMP content of Phlebotomus argentipes Annandale and Brunetti, the main vector of human kalaazar. J Parasitol 87: 915-917.

RIBEIRO JM AND SPIELMAN A. 1986. Ixodes dammini: salivary anaphylatoxin inactivating activity. Exp Parasitol 62: 292-297.

Ribeiro JM and Valenzuela JG. 1999. Purification and cloning of the salivary peroxidase/catechol oxidase of the mosquito Anopheles albimanus. J Exp Biol 202: 809-816.

Ribeiro JM AND WALKer FA. 1994. High affinity histamine-binding and antihistaminic activity of the salivary nitric oxide-carrying heme protein (nitrophorin) of Rhodnius prolixus. J Exp Med 180: 2251-2257.

Ribeiro JM, MAKoul GT, LEVINE J, Robinson DR AND SPIElman A. 1985. Antihemostatic, antiinflammatory, and immunosuppressive properties of the saliva of a tick, Ixodes dammini. J Exp Med 161: 332-344.

Ribeiro JM, Mather TN, Piesman J ANd SpielMAN A. 1987. Dissemination and salivary delivery of Lyme disease spirochetes in vector ticks (Acari: Ixodidae). J Med Entomol 24: 201-205.

Ribeiro JM, WeIS JJ AND TELFORD SR-3RD. 1990. Saliva of the tick Ixodes dammini inhibits neutrophil function. Exp Parasitol 70: 382-388.

Ribeiro JM, HAZZARd JM, NusSEnZVEIG RH, Champagne DE and Walker FA. 1993. Reversible binding of nitric oxide by a salivary heme protein from a bloodsucking insect. Science 260: $539-541$

Ribeiro JM, Schneider M AND Guimaraes JA. 1995. Purification and characterization of prolixin $\mathrm{S}$ (nitrophorin 2), the salivary anticoagulant of the blood-sucking bug Rhodnius prolixus. Biochem J 308 (Pt 1): 243-249.

Ribeiro JM, SchNeider M, IsAias T, JURberG J, GalvaO C And Guimaraes JA. 1998. Role of salivary antihemostatic components in blood feeding by triatomine bugs (Heteroptera). J Med Entomol 35: 599-610.

Ribeiro JM, Katz O, Pannell LK, Waitumbi J AND WARburg A. 1999. Salivary glands of the sand fly Phlebotomus papatasi contain pharmacologically active amounts of adenosine and 5'-AMP. J Exp Biol 202: 1551-1559.

Ribeiro JM, Charlab R and Valenzuela JG. 2001. The salivary adenosine deaminase activity of the mosquitoes Culex quinquefasciatus and Aedes aegypti. J Exp Biol 204: 2001-2010.

Rocha AC, Braga EM, Araujo MS, Franklin BS AND Pimenta PF. 2004. Effect of the Aedes fluviatilis saliva on the development of Plasmodium gallinaceum infection in Gallus (gallus) domesticus. Mem Inst Oswaldo Cruz 99: 709-715. 
Rogers KA AND Titus RG. 2003. Immunomodulatory effects of Maxadilan and Phlebotomus papatasi sand fly salivary gland lysates on human primary in vitro immune responses. Parasite Immunol 25: 127-134.

Romano A, LAdiJinsky E ANd Aboud M. 1983. Effect of hyaluronidase on cell response to the antiviral and interferon inducing activity of poly(rI) . poly(rC). Arch Virol 78: 315-319.

SAmuelson J, Lerner E, Tesh R And Titus R. 1991. A mouse model of Leishmania braziliensis braziliensis infection produced by coinjection with sand fly saliva. J Exp Med 173: 49-54.

SANDEMAM RM. 1996. Immune responses to mosquitoes and flies. In: WIKEL SK (Ed), The Immunology of Host-ectoparasitic Arthropod Relationships. CAB International, Wallingford, p. 175-203.

SCHNEIDER BS, SOONG L, ZeIDNER NS AND HigGS S. 2004. Aedes aegypti salivary gland extracts modulate anti-viral and TH1/TH2 cytokine responses to sindbis virus infection. Viral Immunol 17: 565-573.

SCHOELER GB AND WiKel SK. 2001. Modulation of host immunity by haematophagous arthropods. Ann Trop Med Parasitol 95: 755-771.

SCHOEler GB, MANweIler SA AND WiKel SK. 1999. Ixodes scapularis: effects of repeated infestations with pathogen-free nymphs on macrophage and T lymphocyte cytokine responses of BALB/c and C3H/HeN mice. Exp Parasitol 92: 239-248.

Schoeler GB, Manweiler SA, Bergman DK AND WIKEL SK. 2000. Influence of repeated infestations with pathogen-free Ixodes scapularis (Acari: Ixodidae) on in vitro lymphocyte proliferation responses of C3H/HeN mice. J Med Entomol 37: 885892.

SCHORDERET S AND BRossARD M. 1993. Changes in immunity to Ixodes ricinus by rabbits infested at different levels. Med Vet Entomol 7: 186-192.

SCHWARTZ BS, RIBEIRO JM AND GOLDSTEIN MD. 1990. Anti-tick antibodies: an epidemiologic tool in Lyme disease research. Am J Epidemiol 132: 58-66.

SCHWARTZ BS, Ford DP, CHILDS JE, ROTHMAN N AND THOMAs RJ. 1991. Anti-tick saliva antibody: a biologic marker of tick exposure that is a risk factor for Lyme disease seropositivity. Am J Epidemiol 134: 86-95.

Shan EZ, Taniguchi Y, Shimizu M, Ando K, Chinzei Y, Suto C, OHTAKi T AND OHTAKi N. 1995. Immunoglobulins specific to mosquito salivary gland proteins in the sera of persons with common or hypersensitive reactions to mosquito bites. $\mathrm{J}$ Dermatol 22: 411-418.

Shaw MK, TILney LG AND MCKeEVER DJ. 1993. Tick salivary gland extract and interleukin-2 stimulation enhance susceptibility of lymphocytes to infection by Theileria parva sporozoites. Infect Immun 61: 1486-1495.

Siegel JP, Sharon M, SMith PL AND LeONARD WJ. 1987. The IL-2 receptor beta chain (p70): role in mediating signals for LAK, NK, and proliferative activities. Science 238: 75-78.

Silva F, Gomes R, Prates D, Miranda JC, ANDRADE B, BARRAL-NetTo M AND BARral A. 2005. Inflammatory cell infiltration and high antibody production in BALB/c mice caused by natural exposure to Lutzomyia longipalpis bites.Am J Trop Med Hyg 72: 94-8.

SMITH KA. 1992. Interleukin-2. Curr Opin Immunol 4: 271-276.

Soares MB, Titus RG, Shoemaker CB, David JR AND BozZA M. 1998. The vasoactive peptide maxadilan from sand fly saliva inhibits TNF-alpha and induces IL- 6 by mouse macrophages through interaction with the pituitary adenylate cyclaseactivating polypeptide (PACAP) receptor. J Immunol 160: 1811-1816.

SOLBACH W AND LASKaY T. 2000. The host response to Leishmania infection. Adv Immunol 74: 275-317.

Spatafora M, Chiappara G, D' Amico D, Volpes D, Melis M, Pace E and Merendino AM. 1991. Prostaglandin E2 down-regulates the expression of tumor necrosis alpha gene by human blood monocytes. Adv Prostaglandin Thromboxane Leukot Res 21B: 521-524.

SPIElman A, Wilson ML, LEVINE JF AND PIESMAN J. 1985. Ecology of Ixodes dammini-borne human babesiosis and Lyme disease. Annu Rev Entomol 30: 439-460. 
STARK KR AND JAMES AA. 1996a. Anticoagulants in vector arthropods. Parasitol Today 12: 430-437.

STARK KR AND JAMES AA. 1996b. Salivary gland anticoagulants in culicine and anopheline mosquitoes (Diptera:Culicidae). J Med Entomol 33: 645-650.

STARK KR AND JAMES AA. 1998. Isolation and characterization of the gene encoding a novel factor Xadirected anticoagulant from the yellow fever mosquito, Aedes aegypti. J Biol Chem 273: $20802-$ 20809.

TElford SR-3RD, DAwson JE, Katavolos P, WARner CK, Kolbert CP ANd Persing DH. 1996. Perpetuation of the agent of human granulocytic ehrlichiosis in a deer tick-rodent cycle. Proc Natl Acad Sci USA 93: 6209-6214.

Telford SR-3RD, Armstrong PM, Katavolos P, FopPa I, GARCIA AS, WILSON ML AND SPIElMAN A. 1997. A new tick-borne encephalitis-like virus infecting New England deer ticks, Ixodes dammini. Emerg Infect Dis 3: 165-170.

Theodos CM AND Titus RG. 1993. Salivary gland material from the sand fly Lutzomyia longipalpis has an inhibitory effect on macrophage function in vitro. Parasite Immunol 15: 481-487.

Theodos CM, Ribeiro JM AND Titus RG. 1991. Analysis of enhancing effect of sand fly saliva on Leishmania infection in mice. Infect Immun 59: 1592-1598.

Theze J, Alzari PM And Bertoglio J. 1996. Interleukin 2 and its receptors: recent advances and new immunological functions. Immunol Today 17 : 481-486.

Titus RG AND Ribeiro JM. 1988. Salivary gland lysates from the sand fly Lutzomyia longipalpis enhance Leishmania infectivity. Science 239: 13061308.

Titus RG AND Ribeiro JM. 1990. The role of vector saliva in transmission of arthropod-borne disease. Parasitol Today 6: 157-160.

Urioste S, Hall LR, Telford SR-3RD AND TITUS RG. 1994. Saliva of the Lyme disease vector, Ixodes dammini, blocks cell activation by a nonprostaglandin E2-dependent mechanism. J Exp Med 180: 1077-1085.
VALENZUEla JG, WALKer FA AND Ribeiro JM. 1995. A salivary nitrophorin (nitric-oxide-carrying hemoprotein) in the bedbug Cimex lectularius. J Exp Biol 198: 1519-1526.

Valenzuela JG, Charlab R, Galperin MY AND Ribeiro JM. 1998. Purification, cloning, and expression of an apyrase from the bed bug Cimex lectularius. A new type of nucleotide-binding enzyme. J Biol Chem 273: 30583-30590.

VAlEnZuela JG, Francischetti IM AND Ribeiro JM. 1999. Purification, cloning, and synthesis of a novel salivary anti-thrombin from the mosquito Anopheles albimanus. Biochemistry 38: 11209-11215.

VAlenzuela JG, BelKaid Y, RowTON E AND RIBEIRO JM. 2001. The salivary apyrase of the bloodsucking sand fly Phlebotomus papatasi belongs to the novel Cimex family of apyrases. J Exp Biol 204: 229-237.

Vargaftig BB, Chignard M and Benveniste J. 1981. Present concepts on the mechanisms of platelet aggregation. Biochem Pharmacol 30: 263-271.

Vogt W. 1974. Activation, activities and pharmacologically active products of complement. Pharmacol Rev 26: $125-169$.

Waitumbi J AND Warburg A. 1998. Phlebotomus papatasi saliva inhibits protein phosphatase activity and nitric oxide production by murine macrophages. Infect Immun 66: 1534-1537.

Wanasen N, Nussenzveig RH, Champagne DE, Soong L And Higgs S. 2004. Differential modulation of murine host immune response by salivary gland extracts from the mosquitoes Aedes aegypti and Culex quinquefasciatus. Med Vet Entomol 18: 191199.

WANG H AND NutTall PA. 1994. Excretion of host immunoglobulin in tick saliva and detection of IgGbinding proteins in tick haemolymph and salivary glands. Parasitology 109: 525-530.

WANG H AND NUtTALl PA. 1995a. Immunoglobulin $\mathrm{G}$ binding proteins in male Rhipicephalus appendiculatus ticks. Parasite Immunol 17: 517-524.

WANG H AND NUTTALl PA. 1995b. Immunoglobulin$\mathrm{G}$ binding proteins in the ixodid ticks, Rhipicephalus appendiculatus, Amblyomma variegatum and Ixodes hexagonus. Parasitology 111: 161-165. 
Warburg A, SARaiva E, LAnZaro GC, Titus RG AND NEVA F. 1994. Saliva of Lutzomyia longipalpis sibling species differs in its composition and capacity to enhance leishmaniasis. Philos Trans R Soc Lond B Biol Sci 345: 223-230.

Wasserman HA, Singh S and Champagne DE. 2004. Saliva of the Yellow Fever mosquito, Aedes aegypti, modulates murine lymphocyte function. Parasite Immunol 26: 295-306.

Weigelt H, Addicks K, Hauck G AND Lubbers DW. 1979. Vitalmicroscopic studies in regard to the role of intraendothelian reactive structures in the inflammatory process. Bibl Anat, p. 11-20.

WIKEL SK. 1979. Acquired resistance to ticks: expression of resistance by $\mathrm{C} 4-$ deficient guinea pigs. Am J Trop Med Hyg 28: 586-590.

WIKEL SK. 1982. Immune responses to arthropods and their products. Annu Rev Entomol 27: 21-48.

WIKEL SK. 1985. Effects of tick infestation on the plaque-forming cell response to a thymic dependent antigen. Ann Trop Med Parasitol 79: 195-198.

WIKEL SK. 1996. Host immunity to ticks. Annu Rev Entomol 41: 1-22.

WIKEL SK. 1999a. Modulation of the host immune system by ectoparasitic arthropods. BioScience 49: 311-320.

WIKEL SK. 1999b. Tick modulation of host immunity: an important factor in pathogen transmission. Int $\mathbf{J}$ Parasitol 29: 851-859.

WIKEL SK AND OSBURN RL. 1982. Immune responsiveness of the bovine host to repeated low-level infestations with Dermacentor andersoni. Ann Trop Med Parasitol 76: 405-414.
Wikel SK, Graham JE AND Allen JR. 1978. Acquired resistance to ticks. IV. Skin reactivity and in vitro lymphocyte responsiveness to salivary gland antigen. Immunology 34: 257-263.

Wikel SK, Ramachandra RN, Bergman DK, BURKOT TR AND PIESMAN J. 1997. Infestation with pathogen-free nymphs of the tick Ixodes scapularis induces host resistance to transmission of Borrelia burgdorferi by ticks. Infect Immun 65: 335-338.

YIN H, NORRIS DE AND LANZARo GC. 2000. Sibling species in the Lutzomyia longipalpis complex differ in levels of mRNA expression for the salivary peptide, maxadilan. Insect Mol Biol 9: 309-314.

Zeidner N, Mbow ML, Dolan M, Massung R, BACA E AND PIESMAN J. 1997. Effects of Ixodes scapularis and Borrelia burgdorferi on modulation of the host immune response: induction of a TH2 cytokine response in Lyme disease-susceptible $(\mathrm{C} 3 \mathrm{H} /$ $\mathrm{HeJ})$ mice but not in disease-resistant (BALB/c) mice. Infect Immun 65: 3100-3106.

Zeidner NS, Higgs S, Happ CM, BeATy BJ AND MILLER BR. 1999. Mosquito feeding modulates Th1 and Th 2 cytokines in flavivirus susceptible mice: an effect mimicked by injection of sialokinins, but not demonstrated in flavivirus resistant mice. Parasite Immunol 21: 35-44.

Zer R, YAroslavski I, Rosen L And Warburg A. 2001. Effect of sand fly saliva on Leishmania uptake by murine macrophages. Int J Parasitol 31: 810-814. 